\title{
Imprinted genes in mouse placental development and the regulation of fetal energy stores
}

\author{
S J Tunster, A B Jensen and R M John \\ Cardiff School of Biosciences, Cardiff University, Museum Avenue, Cardiff, Wales CF10 3AX, UK \\ Correspondence should be addressed to R M John; Email: johnrm@cardiff.ac.uk
}

\begin{abstract}
Imprinted genes, which are preferentially expressed from one or other parental chromosome as a consequence of epigenetic events in the germline, are known to functionally converge on biological processes that enable in utero development in mammals. Over 100 imprinted genes have been identified in the mouse, the majority of which are both expressed and imprinted in the placenta. The purpose of this review is to provide a summary of the current knowledge regarding imprinted gene function in the mouse placenta. Few imprinted genes have been assessed with respect to their dosage-related action in the placenta. Nonetheless, current data indicate that imprinted genes converge on two key functions of the placenta, nutrient transport and placental signalling. Murine studies may provide a greater understanding of certain human pathologies, including low birth weight and the programming of metabolic diseases in the adult, and complications of pregnancy, such as pre-eclampsia and gestational diabetes, resulting from fetuses carrying abnormal imprints. Reproduction (2013) 145 R117-R137
\end{abstract}

\section{Introduction}

The first evidence that both parental genomes are required for correct extraembryonic development in mammals came from studies on uniparental embryos generated by microsurgical manipulation of newly fertilised mouse embryos. Gynogenetic and parthenogenetic (two maternal genomes) embryos appear relatively normal but are growth restricted and die around embryonic day (E) 10 with abnormal development of the extraembryonic tissue. In contrast, androgenetic (two paternal genomes) embryos are both developmentally delayed and growth restricted, dying around E8.5, with an abundance of hyperplastic extraembryonic tissue (Kaufman et al. 1977, Surani \& Barton 1983, Barton et al. 1984, McGrath \& Solter 1984, Surani et al. 1986). Studies of uniparental disomic (UPD) embryos further highlighted the functional requirement for both parental genomes at certain chromosomal regions in placental development (Cattanach \& Kirk 1985, Searle \& Beechey 1990, McLaughlin et al. 1996, Cattanach et al. 2004). To date, over 100 imprinted genes have been identified in the mouse, the majority of which are both expressed and imprinted in the placenta (Table 1). Furthermore, $X$-linked genes that undergo inactivation can also be considered imprinted in the mouse placenta (Takagi \& Sasaki 1975, West et al. 1977).

While imprinted genes have traditionally been described as genes that exhibit monoallelic expression in a parent-of-origin-dependent manner (Mochizuki et al. 1996, Pfeifer 2000, Ferguson-Smith \& Surani 2001, Reik \& Walter 2001), such a definition belies the complex expression patterns exhibited by imprinted genes, with many displaying preferential, rather than strict monoallelic, expression of parental alleles (Khatib 2007). Some genes are imprinted in all cell types, while others are imprinted in only a subset (Deltour et al. 1995, Hu et al. 1998, Yu et al. 1998, Charalambous et al. 2003, Dockery et al. 2009). In particular, a number of genes imprinted in the placenta are not imprinted in the embryo (Hudson et al. 2010, Okae et al. 2012). Thus, genomic imprinting more accurately describes the complete or partial parental-allele-biased expression of a gene in one or more cell types.

\section{Development and structure of the mouse placenta}

The development of the mouse placenta and the characteristics and functions of the trophoblast cell types have been extensively reviewed (Rossant \& Cross 2001, Watson \& Cross 2005). Here, we briefly describe key features of placental development in the mouse relevant to this review.

The trophoblast is the first discernable lineage to arise during embryogenesis, which by E3 of development forms a monolayer of trophectoderm encasing the inner cell mass (ICM; Fig. 1A). Following implantation at E4.5, the trophoblast cells overlying the ICM proliferate inwards to form the extraembryonic ectoderm and outwards to form the ectoplacental cone (Fig. 1B). 

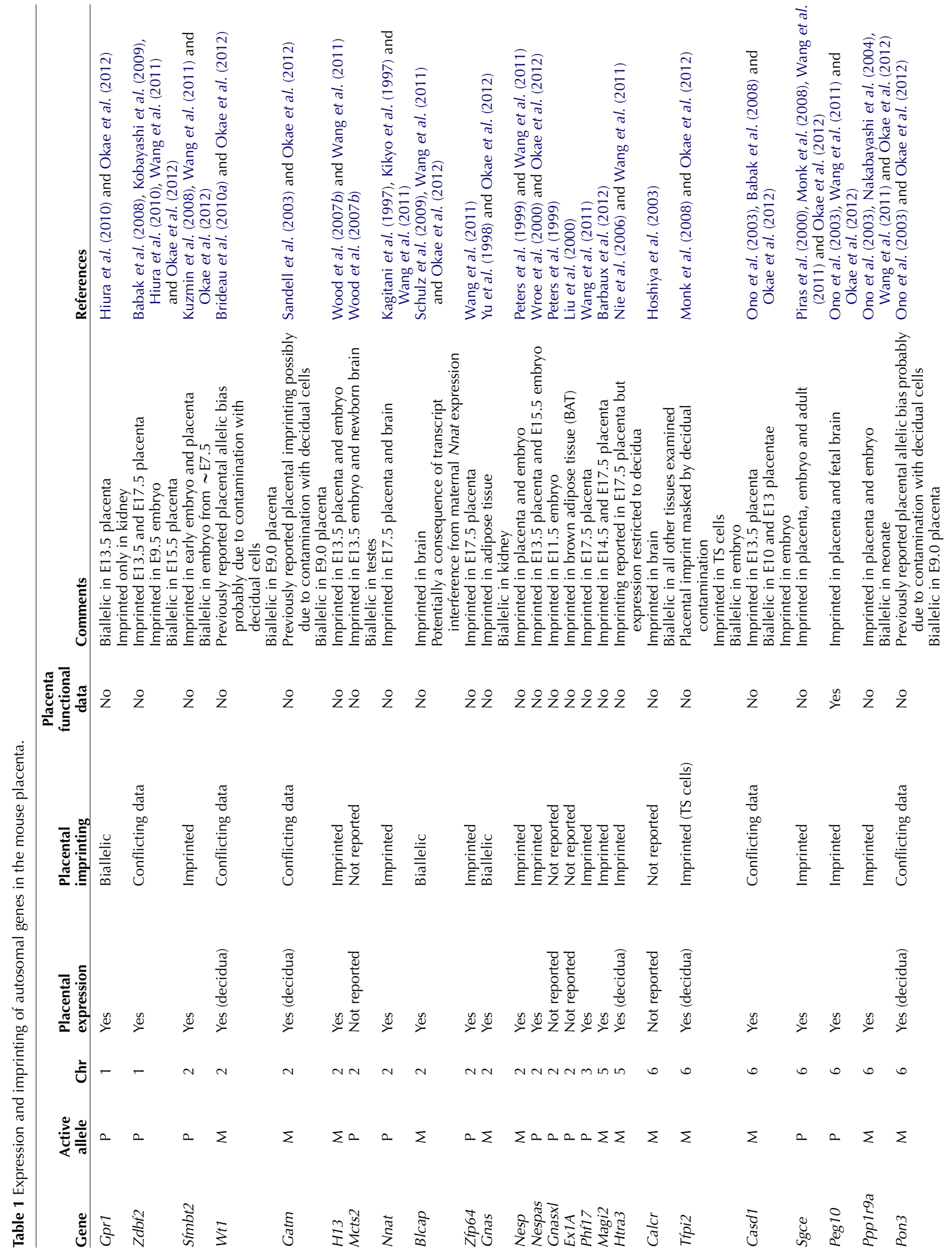

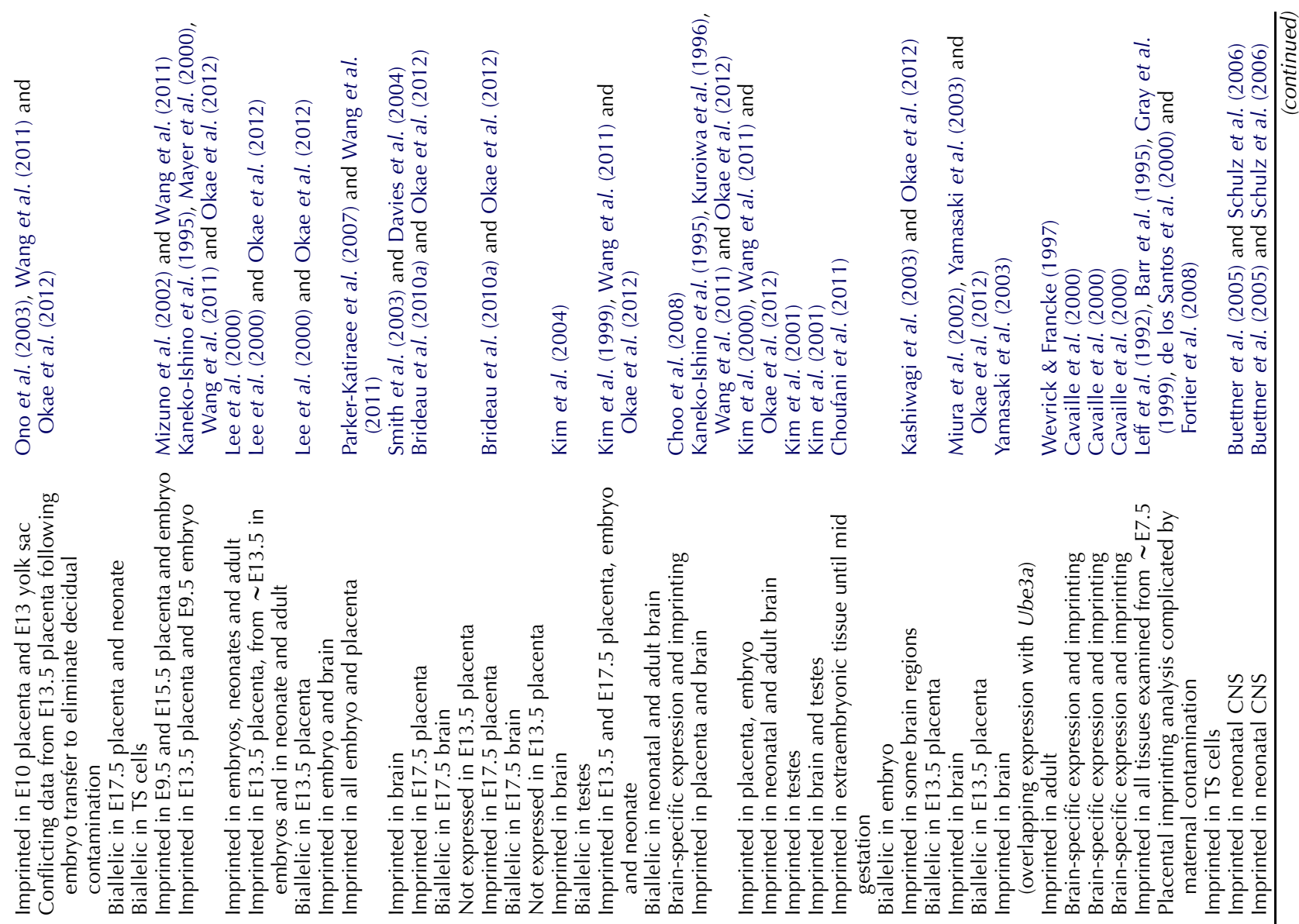

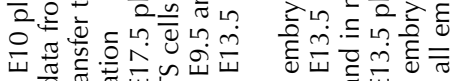

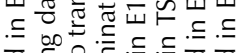

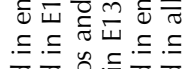

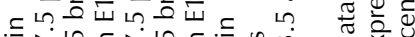

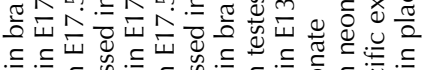

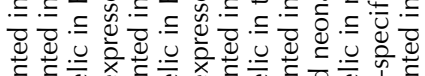

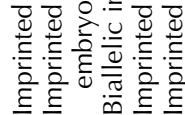

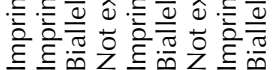

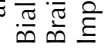

in

In

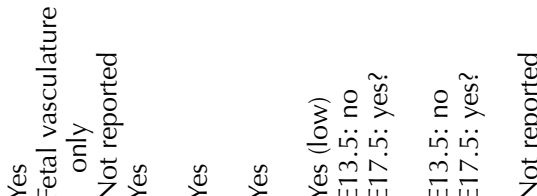<smiles>C1[C@H]2C[C@H]12</smiles> 


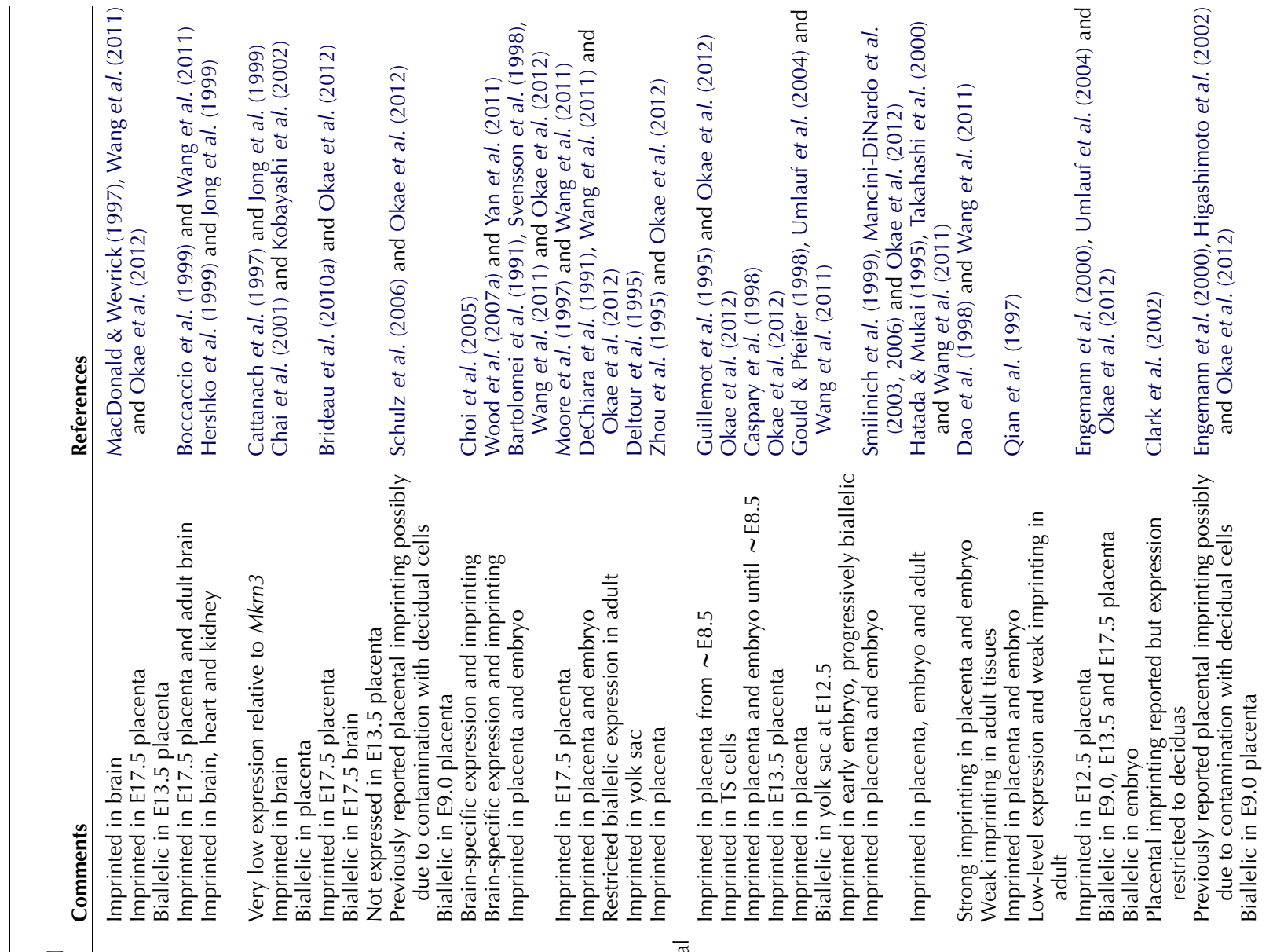

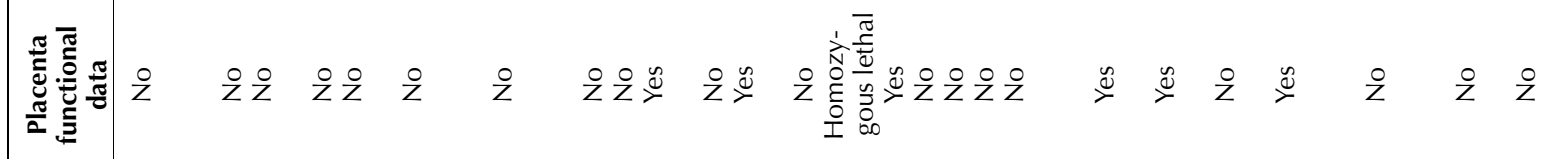
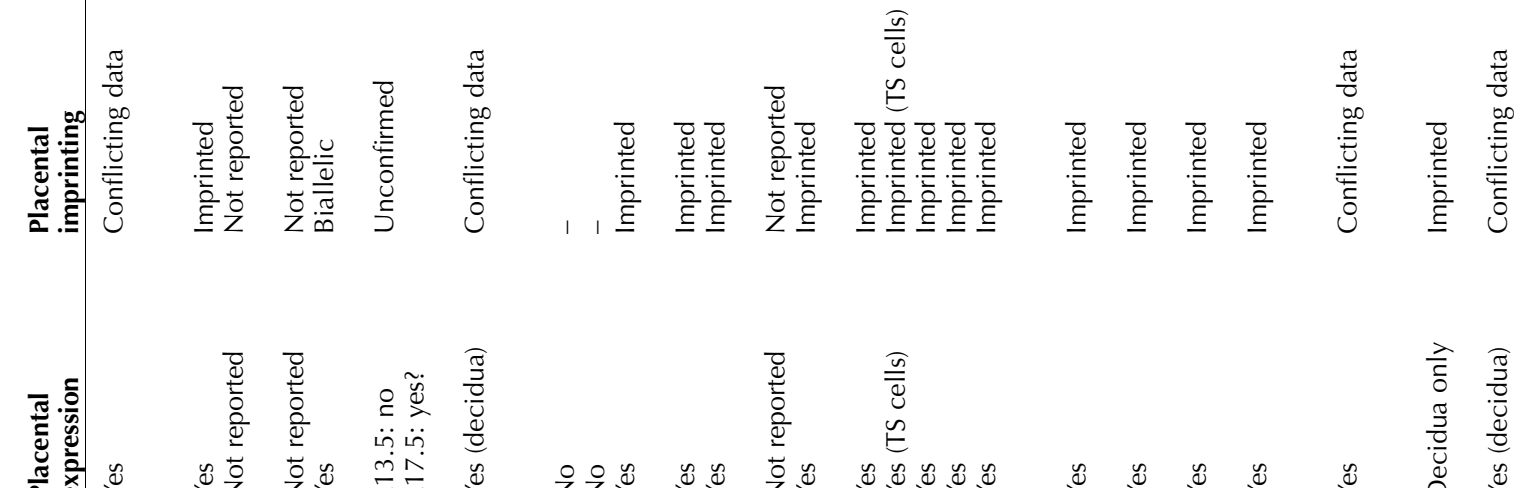

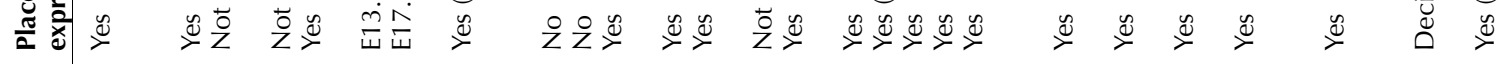

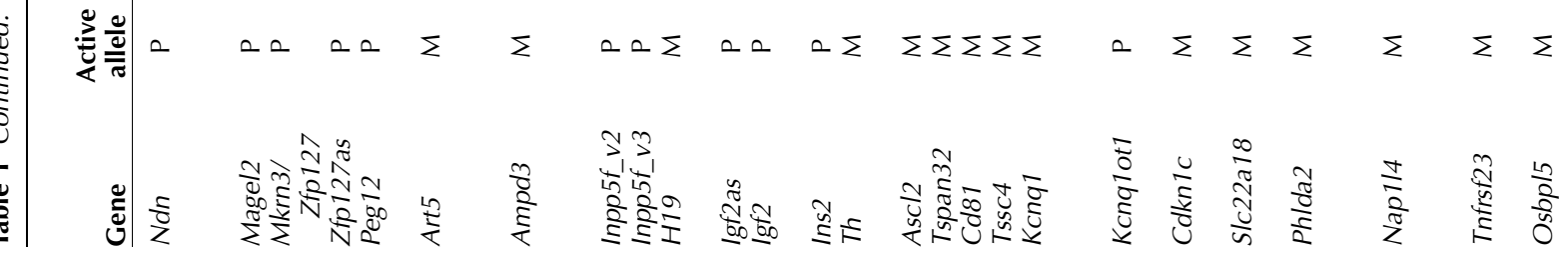



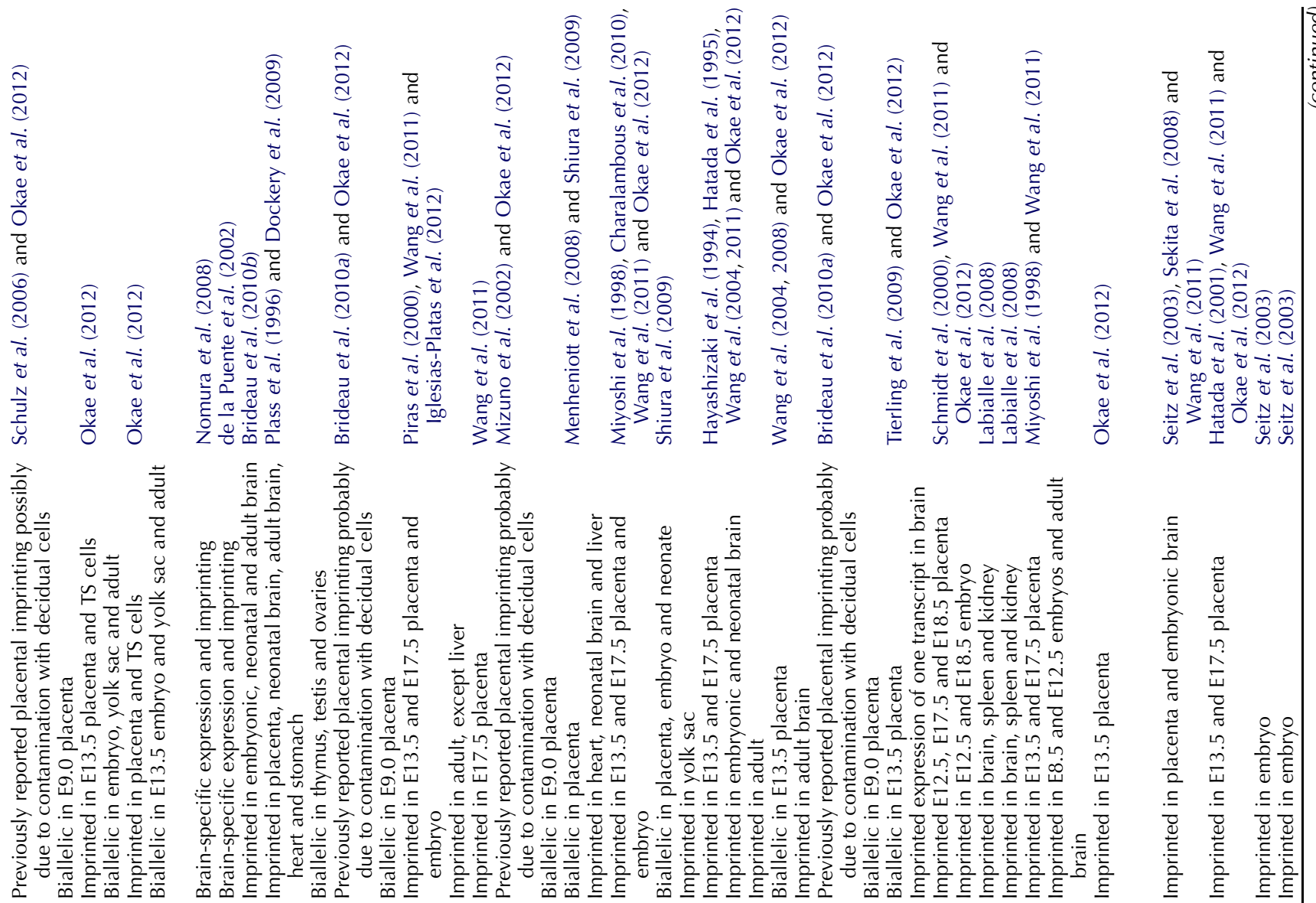

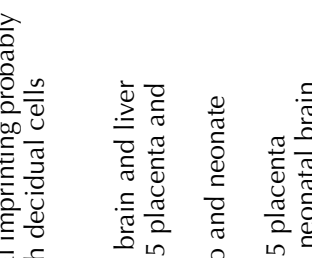
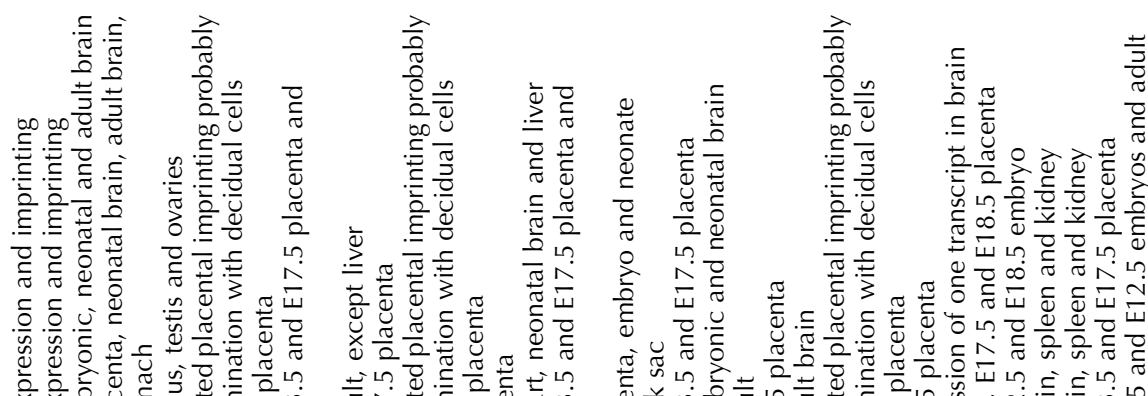

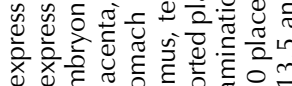

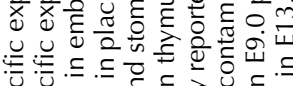

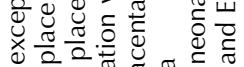

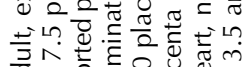

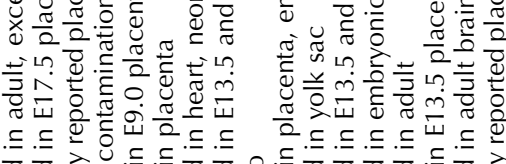

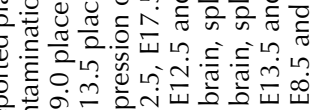

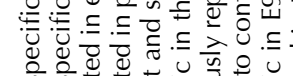

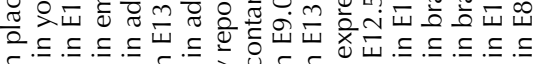

क人.

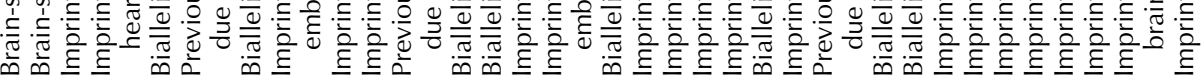

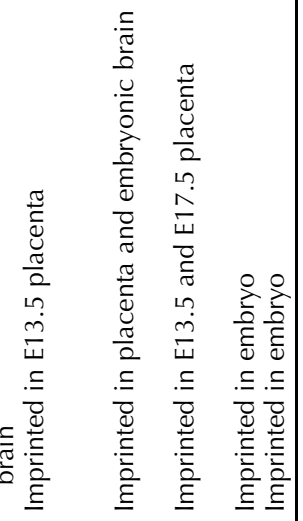

$\circ \quad \circ$ 就

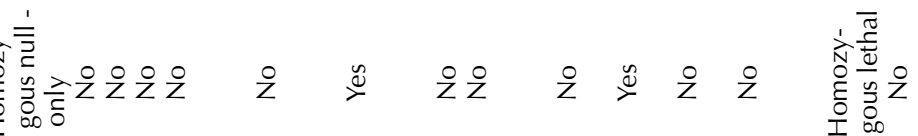

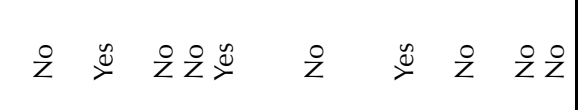
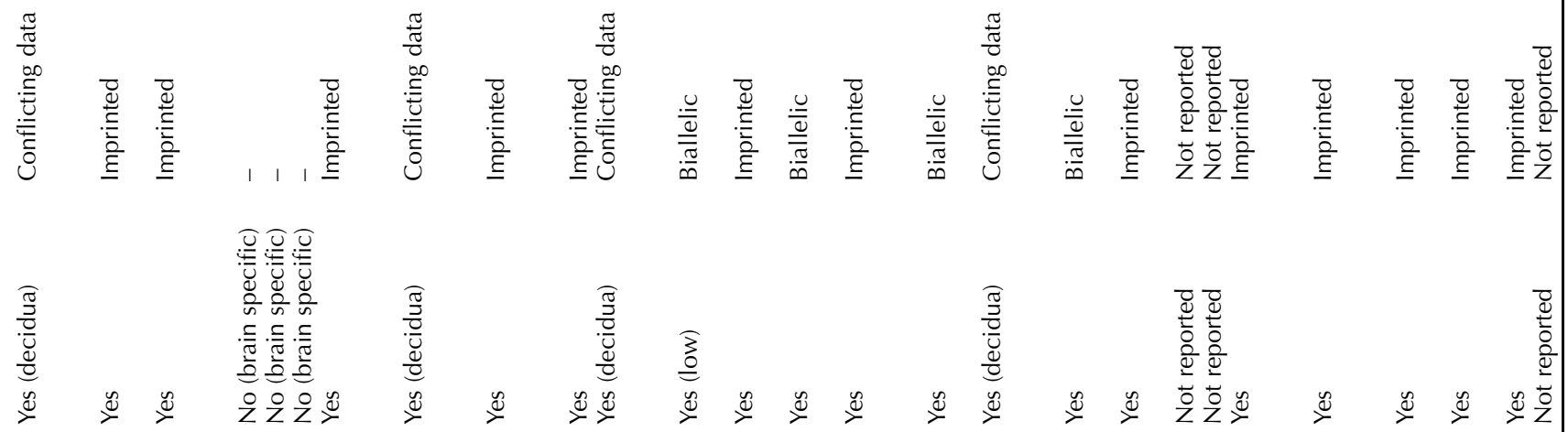

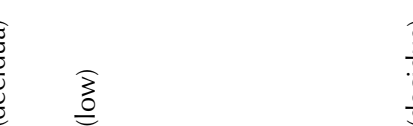<smiles>[CH]1[CH]C=C1</smiles>

焉离

$\wedge \wedge$

$\log \theta$

$\circ \quad \circ$

$=\Sigma=\mp \simeq$

$\simeq \simeq \simeq \simeq \simeq$

$\simeq \simeq \simeq \simeq \simeq$

$\Sigma \quad \Sigma a$

$\cos a$

$a$

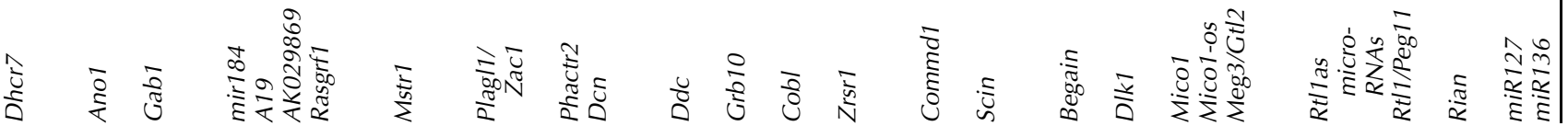




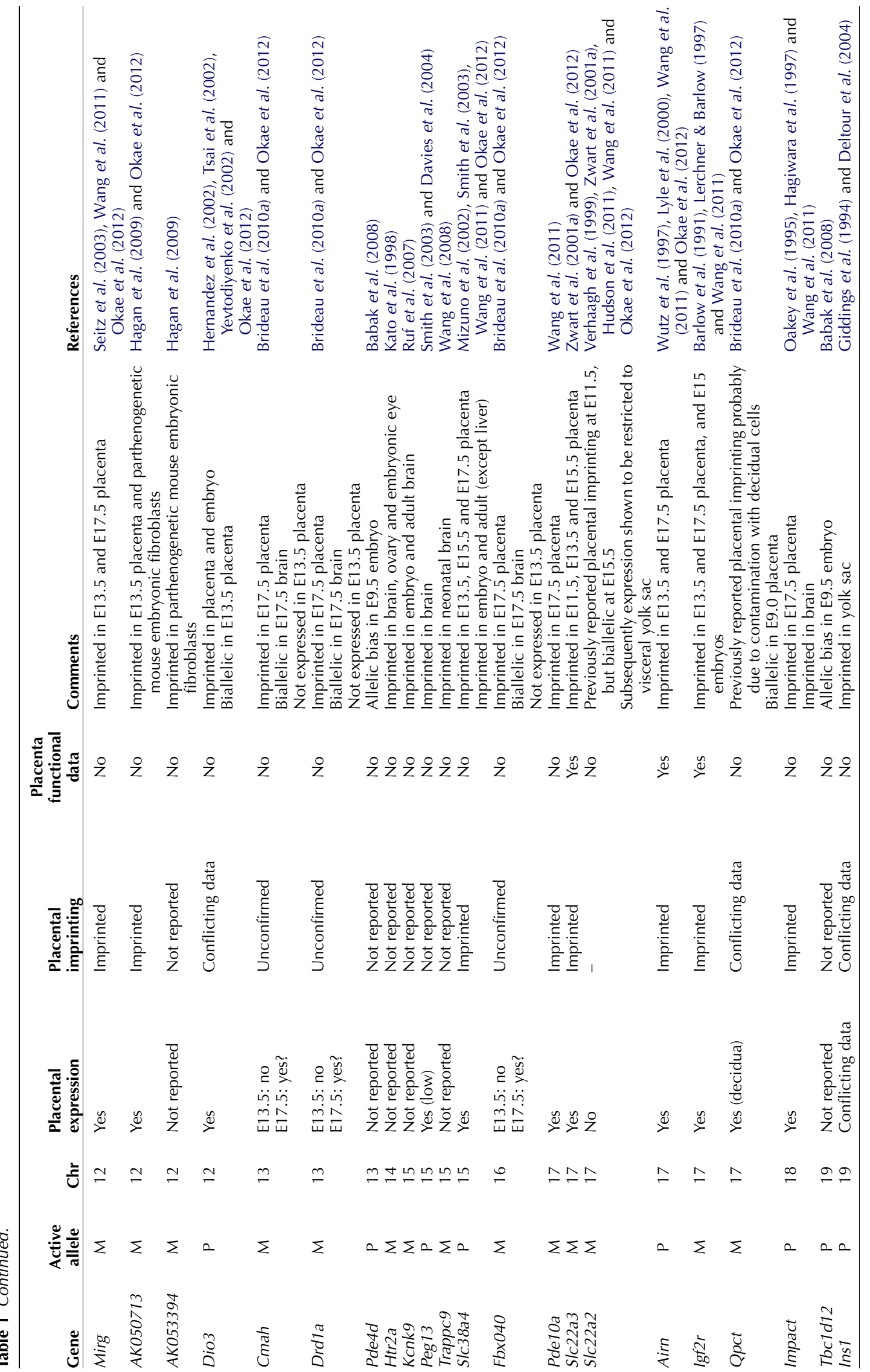


Expansion and differentiation of the ectoplacental cone gives rise to the junctional zone, with cells at the maternal edge undergoing endoreduplication and forming a monolayer of parietal trophoblast giant cells (P-TGCs), although only half of this population of TGCs is derived from ectoplacental cone precursors (Simmons et al. 2007). Proliferation of the extraembryonic ectoderm generates the chorionic epithelium that initially forms a flat 'chorionic plate' at the base of the placenta and eventually gives rise to the labyrinth layer (Fig. 1C).

By midgestation ( $\sim \mathrm{E} 12.5)$, the mouse placenta comprises the labyrinth and junctional zones that together form the fetal-placenta, with proliferation and remodelling of the endometrial lining of the uterine wall at the implantation site forming the maternal decidua. At least eight trophoblast-derived cell types contribute to the fetal-placenta (John \& Hemberger 2012), including four TGC subtypes with characteristic gene expression profiles and spatial localisation (Simmons et al. 2007). A monolayer of P-TGCs lines the implantation site forming a boundary between the fetal junctional zone and maternal decidua. Maternal spiral arteries penetrating the decidua are lined by spiral artery-associated trophoblast giant cells (SpA-TGCs), with canal-associated trophoblast giant cells (C-TGCs) surrounding maternal blood canals traversing the spongiotrophoblast and penetrating the labyrinth layer. A single layer of mononuclear sinusoidal trophoblast giant cells (S-TGCs) replaces the endothelial lining of maternal blood sinuses in the labyrinth through which maternal blood is drained from the placenta (Simmons \& Cross 2005, Simmons et al. 2007).

In the labyrinth, a bilayer of multinucleated syncytiotrophoblast cells formed by cell fusion completes the characteristic trilaminar cellular structure along with the S-TGCs (Rossant \& Cross 2001, Simmons \& Cross 2005, Watson \& Cross 2005, Simmons et al. 2008a). The junctional zone comprised spongiotrophoblast and glycogen cells, both of which express trophoblastspecific protein alpha (Tpbpa), which can be consequently used to identify these cells. Although formation of the junctional zone is essential for completion of embryogenesis (Guillemot et al. 1994), the precise functions of the two junctional zone cell types remain to be confirmed experimentally. Expression of protocadherin 12 (Pcdh12) specifically marks glycogen cells from E7.5 (Bouillot et al. 2005), with stores of glycogen primarily accumulating from E12.5, and migration of glycogen cells into the maternal decidua occurring from $\sim$ E14.5 (Adamson et al. 2002, Coan et al. 2006). These glycogen stores are thought to provide a source of energy for late-gestation embryonic growth and parturition (Coan et al. 2006). In contrast, the spongiotrophoblast cells, which form the bulk of the junctional zone, are thought to perform an endocrine role in synthesising and secreting a range of prolactin-related $(\mathrm{Prl})$ proteins and pregnancy-specific glycoproteins (Psgs) that act to modulate maternal physiology in response to pregnancy (Kromer et al. 1996, Wynne et al. 2006, Simmons et al. 2008b).

\section{UPD and identification of imprinted regions}

The purpose of this review is to provide a summary of the current knowledge regarding imprinted gene function in the placenta with respect to the various placental lineages. While the majority of imprinted genes reported are expressed in the placenta (Table 1), the precise spatial and temporal expression patterns have been described for a subset (Table 2).

The search for imprinted genes with placental functions was initially directed by the observation of placental defects associated with inheritance of monoparental chromosomal regions (Fig. 2A). Such studies suggested the presence of imprinted genes with placental functions residing on proximal chromosomes 2, 7 and 11 and distal chromosome 7 (Cattanach \& Kirk 1985, Searle \& Beechey 1990, Cattanach et al. 1996, 2004, McLaughlin et al. 1996, 1997). Embryonic growth defects associated with UPD of proximal chromosomes 6 and 18 and distal chromosome 12, in addition to the embryonic lethality associated with UPD of proximal chromosome 17 (Johnson 1974, Winking \& Silver 1984, Oakey et al. 1995, Beechey 2000, Georgiades et al. 2000, 2001, Tevendale et al. 2006), may also suggest placental defects.

\section{Distal chromosome 7}

The most extensively characterised of all imprinted regions in the mouse is distal chromosome 7 . Maternal UPD of this region results in impaired fetal and placental growth, with death by E17.5. Paternal UPD of the same region results in a loss of the placental junctional zone and embryonic developmental delay and lethality by E10.5 (Searle \& Beechey 1990, McLaughlin et al. 1996, 1997). Two mechanistically distinct imprinted domains, IC1 and IC2, are located on distal chromosome 7, with imprinting of each domain regulated through independent mechanisms.

The IC1 domain comprises the paternally expressed $\operatorname{lgf2}$ I Iffas and Ins2 genes and the maternally expressed non-coding H19 RNA. The function of this domain in placental development has been reviewed recently and extensively (Lefebvre 2012, Sandovici et al. 2012); therefore, we will give a brief review here. Igf2 is widely expressed in the placenta, with transcription of murine Igf2 initiated from four promoters; P1, P2 and P3 driving expression in fetal endothelium, TGCs, spongiotrophoblast and, most highly, in glycogen cells, with a P0 transcript driving additional expression specifically in labyrinthine cell layers. Studies have been undertaken 

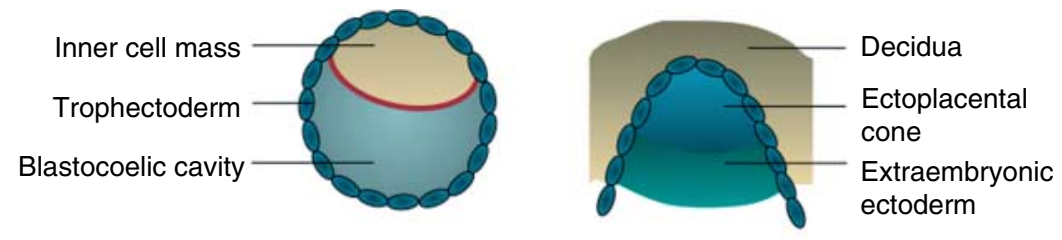

C $\quad \mathrm{E} 12.5$

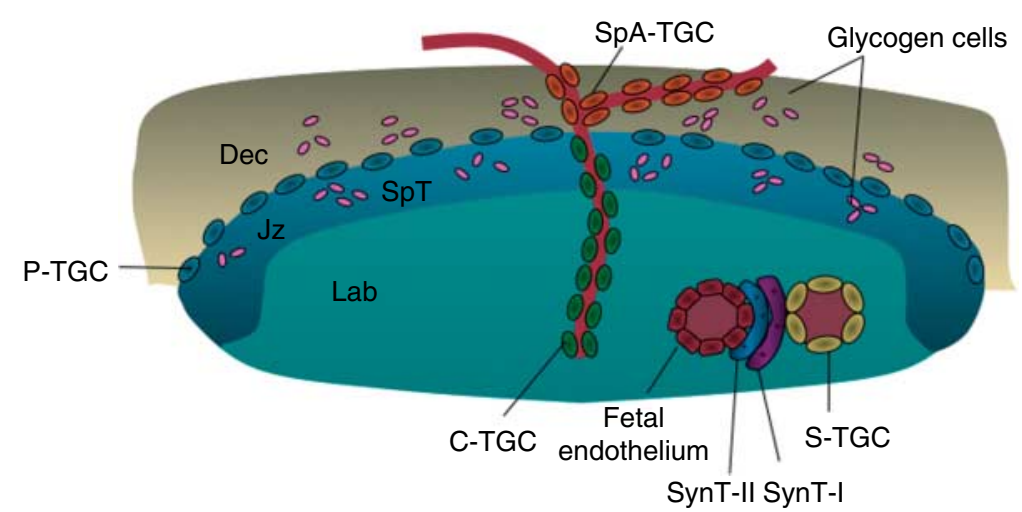

Figure 1 Major stages of placental development in the mouse. (A) Before implantation, the blastocyst comprises a monolayer of trophectoderm encasing the inner cell mass (ICM). (B) Proliferation of the trophoblast overlying the ICM forms the extraembryonic ectoderm and ectoplacental cone. (C) By mid gestation, expansion and differentiation of the ectoplacental cone forms the junctional zone with proliferation of the extraembryonic ectoderm generating the chorionic epithelium and eventually the labyrinth layer. The mature mouse placenta comprises at least eight trophoblast-derived cell types contributing to the fetal-derived labyrinth layers and junctional zone. Dec, maternal decidua; Jz, junctional zone; Lab, labyrinth; SpT, spongiotrophoblast; SpA-TGC, spiral artery-associated trophoblast giant cell; P-TGC, parietal trophoblast giant cell; C-TGC, canal trophoblast giant cell; S-TGC, trophoblast giant cell; SynT-I and SynT-II, syncytiotrophoblast layers I and II. for both complete loss of function of Igf2 and isolated loss of the P0 transcript. Loss of all paternal Igf2 transcripts results in reduced placental weight, attributed to a disproportionate loss of the labyrinth layer and an $80 \%$ loss of the glycogen cell lineage, with reduced staining for placental glycogen. Loss of only the P0 transcript results in a proportionate reduction of both labyrinth and junctional zones, despite only $10 \%$ of total placental Igf2 transcripts initiating at this promoter. Increased transport efficiency is observed in $\operatorname{lgf} 2 \mathrm{PO}^{+/-}$ placentae but not in $\operatorname{lgf} 2^{+/-}$placentae, suggesting an adaptive response to the imbalance between demand for nutrients by the growing embryo and supply capacity of the placenta. To some extent, the consequence of elevated lgf2 expression on placental development can be inferred from studies in which the imprinting centre for Igf2 is disrupted. As this entails loss of expression of the mechanistically linked H19 gene, either through direct targeting of $\mathrm{H} 19$ or indirectly via loss of the imprint, placental phenotypes may reflect elevated Igf2, loss of H19, loss of the microRNA miR675, contained within $\mathrm{H19}$, or a combination of these changes. Loss of imprinting (LOI) at the $\mathrm{H} 19$ domain $\left(H 19^{\Delta 13}\right)$ results in fetal overgrowth and placentomegaly with a 2.5 -fold expansion of the glycogen cell population. Placental glycogen stores are also significantly increased in mutant placentae at E15.5, but with no significant difference at E18.5, suggesting that these stores are either utilised by the overgrowing embryo or that the mutant placenta is unable to sustain them.

The adjacent IC2 domain contains a number of genes expressed and imprinted in the placenta with LOI of this domain, either through targeted deletion of the imprinting centre or termination of the long non-coding RNA
Kcnq1ot1 resulting in placental growth restriction with a compromised junctional zone (Fitzpatrick et al. 2002, Salas et al. 2004, Mancini-Dinardo et al. 2006). Within this domain, the three maternally expressed imprinted genes Ascl2, Cdkn1c and Phlda2 have garnered the most interest with respect to placental development. Ascl2 was the first imprinted gene to be shown to be absolutely required for embryonic viability (Guillemot et al. 1994). Ascl2 switches from biallelic to monoallelic expression in the trophoblast cells at $\sim$ E8.5 (Tanaka et al. 1999). Ascl2 is expressed abundantly in the ectoplacental cone and at lower levels in the chorionic epithelium at E8.5, becoming restricted to a subset of cells at E12.5 with expression undetectable by E18.5 (Rossant et al. 1998). Embryos inheriting a mutant Ascl2 allele from their mother die at midgestation with a complete absence of junctional zone, expanded P-TGC layer and defective labyrinth development (Guillemot et al. 1994, 1995). Ascl2 has since been confirmed to be essential for the differentiation of ectoplacental cone precursors into the established junctional zone cell types but is not essential for differentiation of the labyrinth from chorionic epithelium. The expanded P-TGC layer of Ascl2 mutant placentae suggests a role for Ascl 2 in maintaining the junctional zone population by preventing their differentiation into P-TGCs. A reduced labyrinth layer has been proposed to reflect a loss of endocrine signalling emanating from the spongiotrophoblast (Tanaka et al. 1997). Deletion of the region between the IC1 and IC2 domains and encompassing the Th gene $\left(\mathrm{Del}^{\mathrm{PAI})}\right.$ results in a twofold reduction in Ascl2 alongside impaired placental and embryonic growth (Lefebvre et al. 2009, Oh-McGinnis et al. 2011). Mutant placentae are characterised by an expansion of P-TGCs, complete 
Table 2 Placental expression patterns of imprinted genes.

\begin{tabular}{lll}
\hline Gene & Placental expression pattern & References \\
\hline Zdbf2 & Spongiotrophoblast & Hiura et al. (2010) \\
Sfmbt2 & Extraembryonic ectoderm (precursor to labyrinth) at E6.5 and E7.5 & Frankenberg et al. (2007) \\
Peg10 & All trophoblast cell types & Ono et al. (2006) \\
Peg1/Mest & Fetal vasculature endothelium & Mayer et al. (2000) \\
Peg3 & Junctional zone, P-TGCs and a subset of labyrinthine cells & Hiby et al. (2001) \\
H19 & All trophoblast cell types & Sasaki et al. (1995) and Svensson et al. (1998) \\
lgf2 & All trophoblast cell types & Redline et al. (1993), Moore et al. (1997) \\
Ascl2 & (Labyrinth-specific transcripts from P0 promoter) & and Constância et al. (2002) \\
Cdkn1c & Labyrinth and junctional zone & Guillemot et al. (1994, 1995) \\
& Highly expressed in labyrinth and glycogen cells & Takahashi et al. (2000) \\
Slc22a3 & Low expression in spongiotrophoblast cells & \\
Slc22a18 & Subset of labyrinth cells & Verhaagh et al. (2001) and Zwart et al. (2001a) \\
Phlda2 & Labyrinth & Tunster et al. (2010) \\
& Ectoplacental cone (E5.5), extraembryonic ectoderm and & Frank et al. (1999, 2002) \\
Plagl1/Zac1 & syncytiotrophoblast & Arima et al. (2005) \\
Grb10 & Labyrinth & Charalambous et al. (2010) \\
Dlk1 & Fetal endothelium and trilaminar labyrinth & da Rocha et al. (2007) \\
Meg3/Gtl2 & Fetal endothelium in labyrinth; some glycogen cells & da Rocha et al. (2007) \\
Rtl1/Peg11 & Fetal endothelium and syncytiotrophoblast in labyrinth; & Sekita et al. (2008)
\end{tabular}

loss of glycogen cells, significant loss of spongiotrophoblast cells and disrupted labyrinth (Oh-McGinnis et al. 2011). This suggests that Ascl2 is required for the development of both the spongiotrophoblast and the glycogen cell lineages, although Phlda2 levels are also twofold elevated in this model and may contribute to the placental phenotype.

Cdkn1c encodes a cyclin-dependent kinase inhibitor that negatively regulates cell proliferation and is highly expressed in P-TGCs, glycogen cells, fetal endothelium, syncytiotrophoblast and some larger S-TGC nuclei dynamically during mid-to-late placental development (Georgiades et al. 2002). Cdkn1c mutant placentae are overgrown on the C57BL/6 strain background with an approximate doubling of spongiotrophoblast and labyrinthine cell number, although TGC and glycogen cell number was found to be unaffected at E17.5 in this early study (Takahashi et al. 2000). We studied Cdkn1c ${ }^{-1+}$ mutants on a 129S2/SvHsd strain background, and while we also observed profound placental overgrowth, the labyrinth of Cdkn1c mutant placentae was severely disrupted at E18.5 with substantial thrombotic lesions, collagen deposits, impaired vascularisation and a severe S-TGC deficit (Tunster et al. 2011). Similar thrombotic lesions were also reported in late-gestation PatUPD7 placentae rescued from lethality by restoration of Ascl2 gene expression (Rentsendorj et al. 2010). We also observed a reduced junctional zone at E18.5, which we determined reflected a specific loss of the spongiotrophoblast lineage by marker analysis. While we found no alteration in expression of the glycogen cell marker Pcdh12, suggesting that expansion of the glycogen cell population was unaffected by loss of expression of $C d k n 1 c$, expression of Gjb3, a marker of mature glycogen cells, was lower. This finding, coupled with a reduction in placental glycogen stores, might explain why $C d k n 1 c^{-1+}$ mutant embryos have a growth advantage even during late gestation but fail to maintain this increased body weight to term.

The maternally expressed gene pleckstrin homologylike domain family a member 2 (Phlda2) encodes a small cytoplasmic protein (Qian et al. 1997, Frank et al. 2002). Although studies on a closely related gene, Phlda3, suggest a role for these $\mathrm{PH}$ domain-only proteins in inhibiting Akt-regulated processes (Kawase et al. 2009), this has not been formally demonstrated for Phlda2. Expression of Phlda2 in the placenta is first detected in the ectoplacental cone following implantation, becoming restricted to the syncytiotrophoblast of the labyrinth layer by E10.5 (Frank et al. 1999). Significant maternal bias of Phlda2 is observed in the placenta and embryonic tissues, with lower level expression and less-stringent imprinting in adult tissues (Qian et al. 1997). Phlda2 null mice exhibit placentomegaly with a disproportionate expansion of the junctional zone and histologically exhibit an abundance of stored glycogen, although no direct quantitation of cell number or glycogen stores was undertaken in this study (Frank et al. 2002). We demonstrated that mice with entopic over-expression of Phlda2 exhibit a disproportionate reduction of the junctional zone with limited glycogen stores and impaired fetal growth during late gestation (Salas et al. 2004, Tunster et al. 2010). Using placental marker analysis, we attributed the reduced size of the junctional zone to a specific loss of spongiotrophoblast cells, with no direct effect on glycogen cell abundance. This suggested the possibility that signals from the spongiotrophoblast modulate glycogen storage (Tunster et al. 2010), although this remains to be shown experimentally. Our unpublished studies on the Ph/da2 null placenta also suggest a spongiotrophoblast defect rather than an expansion of the glycogen cell lineage. 
A Chromosomal locations of imprinted genes expressed in the mouse placenta that are located in chromosomal regions

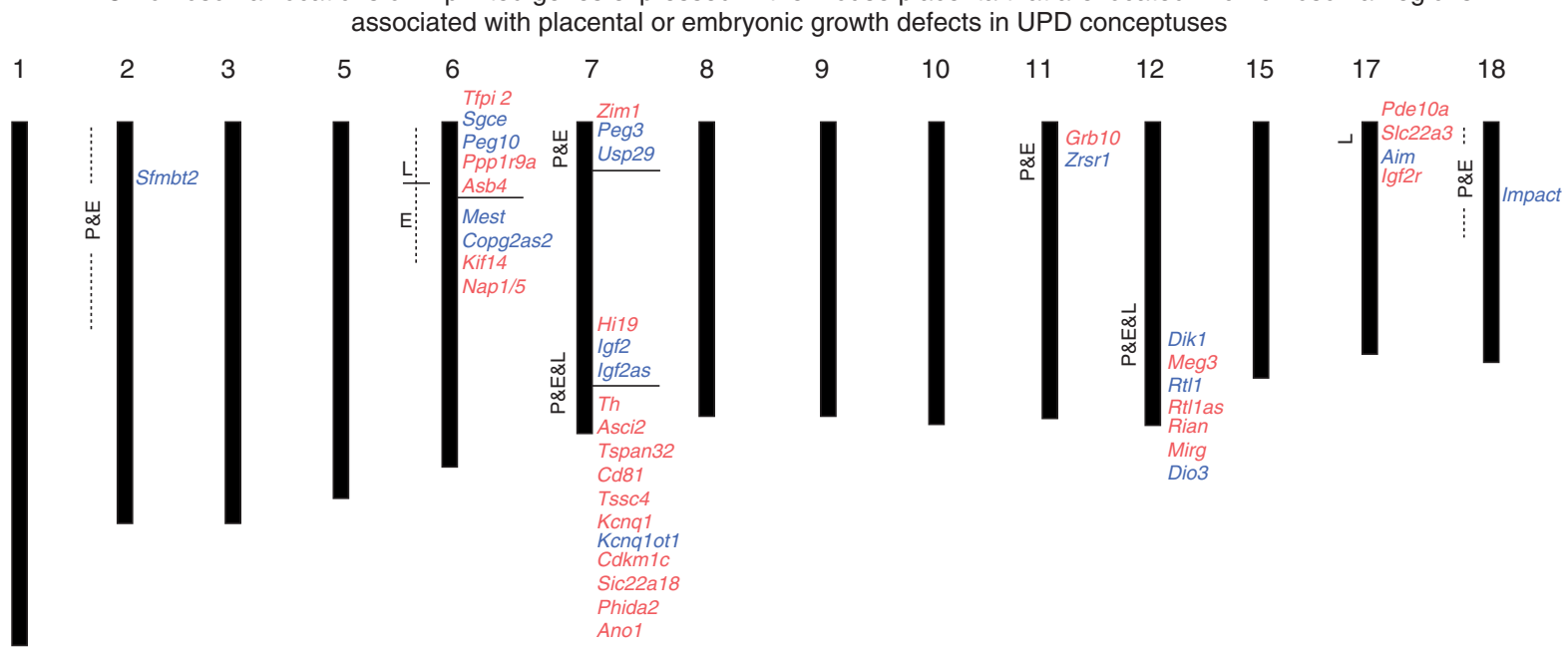

Chromosomal locations of imprinted genes expressed in the mouse placenta but not associated with placental or
embryonic growth defects in UPD conceptuses

Figure 2 Chromosomal locations of genes expressed and imprinted in the mouse placenta. (A) Genes with confirmed imprinted expression in the mouse placenta that map to chromosomal regions associated with embryonic and/or placental phenotypes after monoparental chromosomal inheritance. (B) Genes with confirmed expression in the mouse placenta that map outside chromosomal regions associated with placental and/or embryonic phenotypes. P, placental phenotype; E, embryonic phenotype; L, embryonic lethality; PN, post-natal phenotype. Adapted from www. mousebook.org/catalog.php?catalog=imprinting.

\section{Proximal chromosome 6}

Two imprinted domains are located in close proximity in the proximal region of chromosome 6. Maternal duplication of the most proximal domain, which contains the paternally expressed Peg10 and Sgce genes, results in embryonic lethality at $\sim$ E11.5. Maternal duplication of the more distal domain, which contains the paternally expressed Mest (Peg1) gene, results in embryonic growth retardation that persists into adulthood (Beechey 2000). Embryonic lethality associated with maternal uniparental inheritance of this region may be attributed to a placental defect as a consequence of loss of the retrotransposon-derived Peg10 (Ono et al. 2006). Peg10 is widely expressed in all trophoblast lineages of the placenta and also in several embryonic tissues including brain and vertebral cartilage. Paternal inheritance of a targeted Peg 10 allele results in relatively normal placental development until $\sim$ E8.5. Embryonic death occurs between E9.5 and E10.5 as a consequence of the failure of spongiotrophoblast and labyrinth trophoblast lineages to differentiate from the ectoplacental cone and extraembryonic ectoderm precursors respectively. Formation of P-TGCs is apparently normal. This differs from the $A s c l 2^{-/+}$phenotype in which this population has expanded. Although glycogen cells were not specifically examined in this study, the complete absence of Tpbpa staining in mutant placenta suggests that these cells also fail to develop. Peg10 thus appears to be required for the differentiation of several trophoblast cell types. Functional analyses in the placenta have not 
been undertaken for the paternally expressed Sgce and eight maternally expressed genes in the Peg10 domain.

The second imprinted domain on mouse chromosome 6 contains the paternally expressed Mest. Mest is not expressed in trophoblast lineages, with expression restricted to fetal endothelial cells of the labyrinth (Mayer et al. 2000). Loss of function results in a placental weight deficit and late gestation embryonic growth restriction, although placental morphology appears otherwise normal (Lefebvre et al. 1998). Placental functions have not been ascertained for the other genes in this domain.

\section{Distal chromosome 12}

Maternal UPD of chromosome 12 results in a placental weight deficit with a proportionate reduction in all three layers, embryonic growth retardation and neonatal lethality. Paternal UPD of chromosome 12 results in placentomegaly affecting all three placental layers from E12.5, with embryos dying during late gestation (Georgiades et al. 2000, 2001). Defective vascularisation of the paternal UPD labyrinth occurs by E15.5, with an increased abundance of glycogen cells at E13.5 that fail to appropriately invade the decidua and do not decline in number towards term as normal (Georgiades et al. 2001). The placental defects can be traced to the most distal region of chromosome 12, with paternal UPD of this region associated with placentomegaly and maternal UPD associated with a placental weight deficit similar to those observed for UPD of the entire chromosome (Tevendale et al. 2006).

The imprinted domain on distal chromosome 12 comprises four paternally expressed protein-coding genes and at least seven maternally expressed noncoding RNAs that give rise to a number of microRNAs (reviewed in Hagan et al. (2009)). Imprinting of the domain is regulated by differential methylation of the intergenic differentially methylated region (IG-DMR), with deletion of this region resulting in biallelic expression of all genes in the domain (Lin et al. 2003).

The paternally expressed Dlk1 marks fetal endothelial cells and a sub-population of glycogen cells (Yevtodiyenko \& Schmidt 2006, da Rocha et al. 2007). Dlk1 mutant placentae have a smaller labyrinth area with reduced vascularisation, but no overall effect on placental weight. In the junctional zone, mutant placentae display an increased abundance of preglycogen, although no quantitation of glycogen stores was undertaken. A conditional deletion of Dlk1 in labyrinth fetal endothelium does not produce any overt placental phenotype, although placental structure was not analysed in this model (Appelbe et al. 2012).

The paternally expressed $R t / 1$ is specifically expressed in fetal endothelial cells of the labyrinth. Rt/1 null mice are growth retarded with reduced viability associated with inheritance of the mutation on a pure $\mathrm{C} 57 \mathrm{BL} / 6$ background. Rt/1-deficient placentae are characterised by a severely disrupted labyrinth and impaired passive transport capacity (Sekita et al. 2008). Overlapping the paternal expression of $R t / 1$ is maternal expression of an antisense $R t / 1$ transcript ( $R t / 1$ as) that is processed into multiple microRNAs that target degradation of the paternal Rtl1 transcript (Seitz et al. 2003, Davis et al. 2005). Maternal inheritance of the Rt/1 null allele disrupts expression of Rt/1as from the maternal allele, thus preventing the targeted cleavage of $R t / 1$ transcripts resulting in over-expression of Rt/1. Elevated Rt/1 expression was associated with placentomegaly characterised by an expanded fetal capillary lumen and defective syncytiotrophoblast, although there was no effect on embryonic weight (Sekita et al. 2008).

Maternal deletion of the Meg3 (Gt/2) promoter and exons $1-5$ is associated with LOI of adjacent genes and results in neonatal death but with apparently normal placental development (Zhou et al. 2010). Paternal inheritance of the same Meg3 deletion was associated with impaired fetal and placental growth and downregulation of Dlk1 and Rt/1 in the placenta but not the embryo (Zhou et al. 2010). The paternally expressed Dio3 encodes a type III iodothyronine deiodinase that inactivates thyroid hormones and is expressed on the trophoblast cell types of the labyrinth layer, although imprinted expression is not established until E15.5 (Hernandez et al. 1999, Tsai et al. 2002, Yevtodiyenko et al. 2002, Okae et al. 2012). No phenotypic characterisation has been reported for specifically altered dosage of Dio3, nor the non-coding RNA designated RNA imprinted and accumulated in nucleus (Rian).

\section{Proximal chromosome 11}

Maternal UPD of chromosome 11 is associated with embryonic and placental growth retardation with paternal UPD leading to overgrowth of both embryo and placenta (Cattanach \& Kirk 1985, Cattanach et al. 1996). Three of the genes located within this domain are expressed biallelically in the placenta ( $D d c, C o b /$ and Commd1). Zrsr1 (U2af1-rs1) resides within intron 1 of Commd1, is paternally expressed in the placenta, and although mice carrying a targeted deletion have been generated, a placental function has not been reported (Hatada et al. 1995, Sunahara et al. 2000).

The most extensively characterised imprinted gene on chromosome 11 is growth factor receptor-bound protein 10 (Grb10). Grb10 expression is restricted to the fetal endothelium, where it is expressed only from the maternal allele, and a subset of trophoblast cells in the labyrinth layer where it is expressed biallelically (Charalambous et al. 2010). Maternal inheritance of a disrupted Grb10 allele results in placental and embryonic overgrowth (Charalambous et al. 2003). The volume occupied by the labyrinth layer was increased by 50\%, although the potential effect on nutrient transport was not quantified (Charalambous et al. 2010). Paternal 
transmission of a disrupted Grb10 DMR results in biallelic expression of Grb10 and largely recapitulates the phenotypes associated with maternal UPD of chromosome 11, with placental and embryonic growth retardation that persists into adulthood (Shiura et al. 2009).

\section{Proximal chromosome 17}

Maternal inheritance of a deletion of proximal chromosome 17 is associated with embryonic lethality (Johnson 1974, Winking \& Silver 1984). This domain contains the maternally expressed IGF2 receptor (Igf2r), a multifunctional receptor that binds a range of ligands (Morgan et al. 1987), and two transporters, Slc22a2 and Slc22a3. Loss of function of Igf2r results in placentomegaly (Wang et al. 1994, Wylie et al. 2003) whereas twofold expression of Igf2r, S/c22a2 and S/c22a3 has no gross effect on placental weights (Wutz et al. 2001). Placental weights were only examined at E17.5 in this study and no histology was reported. It remains possible that there might be an earlier or subtle placental phenotype resulting from elevated $\lg f 2 r$.

Slc22a3 is expressed exclusively in a subset of cells of the labyrinth layer (Verhaagh et al. 2001, Zwart et al. 2001a), whereas Slc22a2 expression is restricted to the visceral yolk sac (Hudson et al. 2011) and is not expressed in the placenta as previously reported (Zwart et al. 2001a). Slc22a3 null mice are viable and fertile with no overt placental defect (Zwart et al. 2001b, Jonker et al. 2003).

\section{Proximal chromosome 7}

Maternal UPD of the proximal domain of chromosome 7 is associated with impaired fetal and placental growth (Searle \& Beechey 1990). Functional data exist only for the paternally expressed Peg3 within this domain, which encodes a zinc finger protein and is widely expressed in the junctional zone and P-TGCs, with weaker expression in a subset of labyrinthine cells (Kuroiwa et al. 1996, Relaix et al. 1996, Hiby et al. 2001). A significant placental weight deficit has been reported in response to Peg3 deficiency (Li et al. 1999), but complete characterisation of the placental Peg3 null phenotype has not been reported.

\section{Proximal chromosome 2}

Thirteen imprinted genes are located on mouse chromosome 2, although not all are imprinted in the placenta (Table 1). Maternal UPD of an extensive proximal region of chromosome 2 is associated with impaired placental and fetal growth, with paternal UPD of the same region associated with overgrowth of the placenta, but not the embryo (Cattanach et al. 2004). The only imprinted protein-coding gene in this region is the paternally expressed Sfmbt2 (Kuzmin et al. 2008), which suggests that this gene may have a role in promoting placental growth.

\section{Proximal chromosome 18}

Maternal and paternal UPD of proximal chromosome 18 is associated with perturbed fetal growth (Oakey et al. 1995), although to date the only imprinted gene reported in this region is the paternally expressed Impact (Hagiwara et al. 1997). No placental characterisation has been reported.

\section{X-linked genes}

The paternally inherited X-chromosome is preferentially inactivated in the extraembryonic tissue of mice, and thus, X-linked genes that undergo inactivation can also be considered imprinted in the mouse placenta (Takagi \& Sasaki 1975, West et al. 1977). The existence of X-linked, imprinted genes with important placental functions was uncovered by studying mice with an $\mathrm{XO}$ karyotype. $\mathrm{XO}$ embryos with a paternal $\mathrm{X}\left(\mathrm{X}^{\mathrm{P} O}\right)$ display impaired ectoplacental cone expansion during early gestation whereas $\mathrm{XO}$ embryos carrying the maternal $\mathrm{X}$ $\left(X^{\mathrm{m}} \mathrm{O}\right)$ do not (Ishikawa et al. 2003).

More recent gene targeting studies have identified five $X$-linked, imprinted genes with placental functions. Esx1 is expressed in cells of the labyrinth layer (Li et al. 1997) with maternal inheritance of a targeted allele resulting in placentomegaly, defective labyrinthine vascularisation and an expansion of the glycogen cell population. The boundary between labyrinth and junctional zones was disrupted, with fluid-filled cysts appearing in the junctional zone in mutant placentae. Consistent with placental insufficiency, Esx 1 mutant mice display a late gestation growth restriction alongside post-natal catchup growth (Li \& Behringer 1998).

Cited1 is expressed in all trophoblast cell types of the placenta, with maternal deletion of Cited1 associated with impaired placental growth and a disruption of the border between the junctional zone and labyrinth. The junctional zone of mutant placenta was enlarged with a concomitant decrease in labyrinthine area. Vascularisation of the labyrinth was defective, with increased sinusoidal spaces resulting in a reduced surface area for nutrient transport (Rodriguez et al. 2004). Consistent with placental insufficiency, mutant embryos were asymmetrically growth restricted during late gestation, with the majority of mutants dying in the neonatal period and survivors exhibiting catch-up growth within 8 weeks of birth (Rodriguez et al. 2004, Novitskaya et al. 2011).

The protein-kinase-encoding Nrk is expressed specifically in the junctional zone. Disruption of the maternal 
copy of Nrk is associated with placentomegaly, with an expansion and disruption of the junctional zone and impaired fetal growth during late gestation. Delivery of litters entirely comprised of mutant conceptuses was significantly delayed, with some pregnant dams dying after failing to deliver by E22, suggesting a role for either the junctional zone or Nrk itself in the induction of labour (Denda et al. 2011).

Deletion of the maternal allele of the ubiquitously expressed $\mathrm{Chm}$ impairs placental growth, with reduction of both labyrinthine and junctional zones and an expansion of the P-TGC layer. Vascularisation of mutant placentae was severely disrupted, with thrombotic lesions observed in some mutants and embryonic lethality by E11.5 (Shi et al. 2004).

Plac1 is widely expressed in cells of both labyrinth and junctional zone. Despite escaping complete paternal $X$ inactivation, maternal inheritance of a targeted Plac1 allele results in placentomegaly with an expansion of the junctional zone and disruption of the boundary with the labyrinth layer. Increased TGCs were observed in the labyrinth of mutant placentae, although these cells were not confirmed as S-TGCs (Jackman et al. 2012).

\section{Imprinted genes not associated with UPD placental phenotypes}

Uniparental inheritance of some chromosomal regions is not associated with overt placental or embryonic growth defects. Additionally, a small number of imprinted genes have been identified that are not associated with established imprinted domains (Fig. 2B). However, this does not preclude a role for such genes in the formation of a functional placenta and awaits further experimental clarification.

Placental imprinting has been reported only for $Z d b f 2$ on chromosome 1. Zbdf2 is highly expressed in the junctional zone, with conserved imprinting of $Z b d f 2$ in human placentae suggestive of an important function (Hiura et al. 2010). Maternal expression of Magi2 and $\mathrm{Htra3}$ has been recently reported on chromosome 5 (Wang et al. 2011, Barbaux et al. 2012). A placental function for Magi2 has not been investigated, whereas Htra3 is expressed exclusively in decidual cells (Nie et al. 2006). HTRA3 inhibits trophoblast invasion in humans (Singh et al. 2010, 2011), although its function in the murine placenta has not been investigated.

The imprinted domain located within the central region of chromosome 7 is referred to as the PraderWilli/Angelman syndromes (PWS-AS) cluster in humans due to the involvement of genes in this region in the imprinted PWS/AS. Within this region, Magel2 is expressed in the placenta (Kozlov et al. 2007), with some Magel2 mutants lost relatively early in development, which may suggest a placental defect (Bischof et al. 2007). Paternal expression of Gab1 on chromosome 8 has recently been reported specifically in the placenta (Okae et al. 2012). Gab1 is expressed in cells of both the labyrinth and junctional zone. Homozygous Gab1 deficiency results in a disproportionate loss of labyrinth layer, with embryonic lethality by E18.5, although heterozygous transmission of the deletion has not been examined (Itoh et al. 2000, Sachs et al. 2000, Schaeper et al. 2007). Five imprinted genes have been identified on distal chromosome 9. Rasgrf1 is expressed in the placenta (Dockery et al. 2009), but maternal UPD of the region is associated only with a post-natal growth restriction phenotype (Itier et al. 1998, Clapcott et al. 2003, Cattanach et al. 2004).

Imprinting of three genes on chromosome 10 has been reported, although a placental function has been reported for only the paternally expressed Plag/1 (Zac1) gene, which encodes an anti-proliferative, proapoptotic zinc finger protein that interacts with an imprinted gene network including Igf2, H19, Cdkn1C and Dlk1 (Spengler et al. 1997, Piras et al. 2000, Arima et al. 2005, Varrault et al. 2006). Plag/1-deficient placenta is lighter than wild type but otherwise morphologically similar to wild type with normal nutrient transport. Mutant embryos are asymmetrically growth restricted during late gestation, indicative of a placental defect (Varrault et al. 2006).

Imprinting of four distally located genes on chromosome 15 has been reported. Placental functions for three of these genes (Kcnk9, Peg13 and Trappc9) have not been investigated. Slc38a4 encodes a member of the system A amino acid transporters that is paternally expressed specifically in the placenta (Mizuno et al. 2002). Although generation of an Slc38a4 null mouse model has been alluded to in recent publications (Coan et al. 2010, Fowden et al. 2011), a complete characterisation of the phenotype has yet to be published.

\section{Discussion}

Our knowledge of the function of imprinted genes in the placenta has advanced considerably since the identification of the first imprinted gene over two decades ago. However, despite the demonstrable importance of imprinted genes in placental development, it is perhaps surprising that placental functions have been characterised in detail for only a minority of these genes (Table 3). Of perhaps greater concern is the assumption that loss-of-function models can be used to formulate hypotheses regarding the function of imprinting in placental development with little acknowledgement that these models fail to address dosage-related function. While loss-of-function models provide invaluable data regarding gene function, they do not address imprint function. 'LOI' models have been generated for some imprinted domains but the interpretation of the resulting phenotypes is confounded by the combined effects of 
Table 3 Phenotypes associated with targeted deletion of imprinted genes.

\begin{tabular}{|c|c|c|c|}
\hline Gene & $\begin{array}{l}\text { Active } \\
\text { allele }\end{array}$ & Phenotype & References \\
\hline Ascl2 & M & Loss of junctional zone, disrupted labyrinth and embryonic lethality & Guillemot et al. (1994, 1995) \\
\hline$C d k n 1 c$ & M & $\begin{array}{l}\text { Placentomegaly } \\
\text { Expansion of labyrinth and spongiotrophoblast on C57BL/ } 6 \\
\text { background } \\
\text { Thrombotic lesions, loss of S-TGCs and failure of glycogen cell } \\
\text { maturation on } 129 / \mathrm{Sv} \text { background }\end{array}$ & Takahashi et al. (2000) and Tunster et al. (2011) \\
\hline Dlk1 & $\mathrm{P}$ & $\begin{array}{l}\text { Reduced size and vascularisation of labyrinth; impaired glycogen } \\
\text { cell differentiation }\end{array}$ & Appelbe et al. (2012) \\
\hline Grb10 & M & Placentomegaly; expansion of labyrinth; embryonic overgrowth & Charalambous et al. $(2003,2010)$ \\
\hline$H 19^{413}(\mathrm{LOI} \operatorname{lgf} 2)$ & M & Placentomegaly and expansion of glycogen cell population & Leighton et al. (1995) and Esquiliano et al. (2009) \\
\hline$H 19^{43}$ & M & Placentomegaly & Keniry et al. (2012) \\
\hline $\lg 2$ & $\mathrm{P}$ & $\begin{array}{l}\text { Placental weight deficit; disproportionate loss of labyrinth, reduced } \\
\text { glycogen storage; intrinsic embryonic growth retardation }\end{array}$ & $\begin{array}{l}\text { DeChiara et al. (1990, 1991) and } \\
\quad \text { Lopez et al. (1996) }\end{array}$ \\
\hline $\operatorname{lgf} 2 \mathrm{PO}$ & $\mathrm{P}$ & $\begin{array}{l}\text { Placental weight deficit; proportionate loss of labyrinth and } \\
\text { junctional zone; late gestation embryonic growth restriction }\end{array}$ & Constância et al. (2002) \\
\hline $\lg f 2 r$ & M & Placentomegaly, fetal overgrowth & Lau et al. (1994) and Ludwig et al. (1996) \\
\hline Kcnq1ot1 & $\mathrm{P}$ & $\begin{array}{l}\text { Placental and embryonic growth deficit } \\
\text { Decreased junctional zone (due to LOI of IC2 domain genes) }\end{array}$ & $\begin{array}{l}\text { Fitzpatrick et al. (2002), Salas et al. (2004) and } \\
\text { Mancini-Dinardo et al. (2006) }\end{array}$ \\
\hline Peg1/Mest & $\mathrm{P}$ & $\begin{array}{l}\text { Placental weight deficit, but normal morphology } \\
\text { Embryonic growth restriction }\end{array}$ & Lefebvre et al. (1998) \\
\hline Peg3 & $\mathrm{P}$ & Placental and embryonic growth deficit & Li et al. (1999) and Hiby et al. (2001) \\
\hline Peg10 & $\mathrm{P}$ & $\begin{array}{l}\text { Failure of junctional zone and labyrinth layer to form } \\
\text { Embryonic lethal by E10.5 }\end{array}$ & Ono et al. (2006) \\
\hline Phlda2 & M & Placentomegaly and disproportionate expansion of junctional zone & Frank et al. (2002) \\
\hline Plag/1/Zac1 & $\mathrm{P}$ & $\begin{array}{l}\text { Placental weight deficit, but normal morphology } \\
\text { Embryonic growth restriction }\end{array}$ & Varrault et al. (2006) \\
\hline Rt/1 & $\mathrm{P}$ & Disruption of labyrinth structure, impaired passive transport & Sekita et al. (2008) \\
\hline
\end{tabular}

both loss of expression and gain-in-expression of multiple imprinted genes. Modelling LOI at the individual gene level is considerably more difficult to achieve, although arguably provides the best evidence to elucidate the advantage of imprinting specific genes while maintaining biallelic expression of others.

As it stands, loss-of-function studies have identified seven imprinted genes that are required for the proper formation of the labyrinthine tissue and thus likely to be directly important for nutrient transport (Table 3). Imprinted genes also functionally converge on the spongiotrophoblast and giant cell lineages, which perform key endocrine functions in maternal physiology, both locally and systemically. The glycogen cell lineage also appears to be a target for several imprinted genes, most notably lgf2. While loss-of-function models may not provide definitive clues as to the evolution of imprinting, further investigation of these models will provide information on the function of various placental lineages, potentially clarifying the function of these cell types in driving the adaptations in maternal physiology that are required for a successful and healthy pregnancy.

One aspect of placental biology that stands out is the relationship between the spongiotrophoblast and glycogen storage. In several models, glycogen stores in a late-gestation placenta correlate more strongly with the amount of spongiotrophoblast present than with the glycogen cell population. For example, elevated Phlda2 results in a failure of the spongiotrophoblast lineage to expand and a subsequent depletion of glycogen stores, despite no apparent effect on expansion of the glycogen cell population. Similarly, loss of function of $C d k n 1 c$ results in a reduction of the spongiotrophoblast lineage alongside a depletion of glycogen stores, but with no overt effect on the glycogen cells. Even with Igf2, where elevated expression is associated with both an increase in glycogen cell number and increased glycogen stores, these stores are not maintained late in gestation, which may reflect the lack of a positive effect of Igf2 on the spongiotrophoblast. We have observed a similar relationship between the spongiotrophoblast lineage and glycogen stores in different strains of inbred mice with C57BL/6 placenta expressing higher levels of spongiotrophoblast-specific markers and carrying considerably higher amounts of glycogen than 129S2/SvHsd placenta (Tunster et al. 2012). Taken together, these data suggest the possibility that signals emanating from the junctional zone promote the uptake and storage of glycogen by the glycogen cell population.

In conclusion, while a great deal of further work is required to assess both the function of imprinted genes in the placenta and the significance of their regulated dosage, current evidence highlights the role of imprinted genes in regulating birth weight both directly and indirectly via placental function. Moreover, the influence of these imprinted genes probably extends beyond early life into adulthood, either as a consequence of the intrinsic activity of the gene or through adaptations that 
have occurred in the fetus in response to poor in utero growth. Finally, aberrant imprinting in the placenta may have a profound effect on the well-being of the mother during pregnancy. Alterations in the expression of members of this relatively obscure family of genes may therefore have profound and wide reaching consequences for human health.

\section{Declaration of interest}

The authors declare that there is no conflict of interest that could be perceived as prejudicing the impartiality of the review.

\section{Funding}

S J Tunster was supported by the Biotechnology and Biological Sciences Research Council (grant numbers BB/G015465/1 and BB/J015156/1). A B Jensen was supported by a Biotechnology and Biological Sciences Research Council Doctoral Training Grant to Cardiff University.

\section{References}

Adamson SL, Lu Y, Whiteley KJ, Holmyard D, Hemberger M, Pfarrer C \& Cross JC 2002 Interactions between trophoblast cells and the maternal and fetal circulation in the mouse placenta. Developmental Biology 250 358-373. (doi:10.1006/dbio.2002.0773)

Appelbe OK, Yevtodiyenko A, Muniz-Talavera H \& Schmidt JV 2012 Conditional deletions refine the embryonic requirement for Dlk1. Mechanisms of Development 130 143-159. (doi:10.1016/j.mod.2012. 09.010)

Arima T, Kamikihara T, Hayashida T, Kato K, Inoue T, Shirayoshi $\mathrm{Y}$, Oshimura M, Soejima H, Mukai T \& Wake N 2005 ZAC, LIT1 (KCNQ1OT1) and p57KIP2 (CDKN1C) are in an imprinted gene network that may play a role in Beckwith-Wiedemann syndrome. Nucleic Acids Research 33 2650-2660. (doi:10.1093/nar/gki555)

Babak T, Deveale B, Armour C, Raymond C, Cleary MA, van der Kooy D, Johnson JM \& Lim LP 2008 Global survey of genomic imprinting by transcriptome sequencing. Current Biology 18 1735-1741. (doi:10.1016/j.cub.2008.09.044)

Barbaux S, Gascoin-Lachambre G, Buffat C, Monnier P, Mondon F, Tonanny MB, Pinard A, Auer J, Bessieres B, Barlier A et al. 2012 A genome-wide approach reveals novel imprinted genes expressed in the human placenta. Epigenetics 7 1079-1090. (doi:10.4161/epi.21495)

Barlow DP, Stoger R, Herrmann BG, Saito K \& Schweifer N 1991 The mouse insulin-like growth factor type-2 receptor is imprinted and closely linked to the Tme locus. Nature 349 84-87. (doi:10.1038/349084a0)

Barr JA, Jones J, Glenister PH \& Cattanach BM 1995 Ubiquitous expression and imprinting of Snrpn in the mouse. Mammalian Genome 6 405-407. (doi:10.1007/BF00355641)

Bartolomei MS, Zemel S \& Tilghman SM 1991 Parental imprinting of the mouse H19 gene. Nature 351 153-155. (doi:10.1038/351153a0)

Barton SC, Surani MA \& Norris ML 1984 Role of paternal and maternal genomes in mouse development. Nature 311 374-376. (doi:10.1038/ 311374a0)

Beechey CV 2000 Peg1/Mest locates distal to the currently defined imprinting region on mouse proximal chromosome 6 and identifies a new imprinting region affecting growth. Cytogenetics and Cell Genetics 90 309-314. (doi:10.1159/000056794)

Bischof JM, Stewart CL \& Wevrick R 2007 Inactivation of the mouse Magel2 gene results in growth abnormalities similar to Prader-Willi syndrome. Human Molecular Genetics 16 2713-2719. (doi:10.1093/ hmg/ddm225)
Boccaccio I, Glatt-Deeley H, Watrin F, Roeckel N, Lalande M \& Muscatelli F 1999 The human MAGEL2 gene and its mouse homologue are paternally expressed and mapped to the Prader-Willi region. Human Molecular Genetics 8 2497-2505. (doi:10.1093/hmg/8.13.2497)

Bouillot S, Rampon C, Tillet E \& Huber P 2005 Tracing the glycogen cells with protocadherin 12 during mouse placenta development. Placenta $\mathbf{2 7}$ 882-888. (doi:10.1016/j.placenta.2005.09.009)

Brideau CM, Eilertson KE, Hagarman JA, Bustamante CD \& Soloway PD 2010a Successful computational prediction of novel imprinted genes from epigenomic features. Molecular and Cellular Biology 30 3357-3370. (doi:10.1128/MCB.01355-09)

Brideau CM, Kauppinen KP, Holmes R \& Soloway PD 2010b A non-coding RNA within the Rasgrf1 locus in mouse is imprinted and regulated by its homologous chromosome in trans. PLoS ONE 5 e13784. (doi:10.1371/ journal.pone.0013784)

Buettner VL, Walker AM \& Singer-Sam J 2005 Novel paternally expressed intergenic transcripts at the mouse Prader-Willi/Angelman syndrome locus. Mammalian Genome 16 219-227. (doi:10.1007/s00335-0042452-7)

Caspary T, Cleary MA, Baker CC, Guan XJ \& Tilghman SM 1998 Multiple mechanisms regulate imprinting of the mouse distal chromosome 7 gene cluster. Molecular and Cellular Biology 18 3466-3474.

Cattanach BM \& Kirk M 1985 Differential activity of maternally and paternally derived chromosome regions in mice. Nature 315 496-498. (doi:10.1038/315496a0)

Cattanach BM, Beechey CV, Rasberry C, Jones J \& Papworth D 1996 Time of initiation and site of action of the mouse chromosome 11 imprinting effects. Genetical Research 68 35-44. (doi:10.1017/\$00166723000 33863)

Cattanach BM, Barr JA, Beechey CV, Martin J, Noebels J \& Jones J 1997 A candidate model for Angelman syndrome in the mouse. Mammalian Genome 8 472-478. (doi:10.1007/s003359900479)

Cattanach BM, Beechey CV \& Peters J 2004 Interactions between imprinting effects in the mouse. Genetics 168 397-413. (doi:10.1534/ genetics.104.030064)

Cavaille J, Buiting K, Kiefmann M, Lalande M, Brannan CI, Horsthemke B, Bachellerie JP, Brosius J \& Huttenhofer A 2000 Identification of brainspecific and imprinted small nucleolar RNA genes exhibiting an unusual genomic organization. PNAS 97 14311-14316. (doi:10.1073/pnas. 250426397)

Chai JH, Locke DP, Ohta T, Greally JM \& Nicholls RD 2001 Retrotransposed genes such as Frat3 in the mouse chromosome 7C Prader-Willi syndrome region acquire the imprinted status of their insertion site. Mammalian Genome 12 813-821. (doi:10.1007/s00335001-2083-1)

Charalambous M, Smith FM, Bennett WR, Crew TE, Mackenzie F \& Ward A 2003 Disruption of the imprinted Grb10 gene leads to disproportionate overgrowth by an Igf2-independent mechanism. PNAS 100 8292-8297. (doi:10.1073/pnas.1532175100)

Charalambous M, Cowley M, Geoghegan F, Smith FM, Radford EJ, Marlow BP, Graham CF, Hurst LD \& Ward A 2010 Maternally-inherited Grb10 reduces placental size and efficiency. Developmental Biology 337 1-8. (doi:10.1016/j.ydbio.2009.10.011)

Choi JD, Underkoffler LA, Wood AJ, Collins JN, Williams PT, Golden JA, Schuster EF Jr, Loomes KM \& Oakey RJ 2005 A novel variant of Inpp5f is imprinted in brain, and its expression is correlated with differential methylation of an internal $\mathrm{CpG}$ island. Molecular and Cellular Biology 25 5514-5522. (doi:10.1128/MCB.25.13.5514-5522. 2005)

Choo JH, Kim JD \& Kim J 2008 Imprinting of an evolutionarily conserved antisense transcript gene APeg3. Gene 409 28-33. (doi:10.1016/j.gene. 2007.10.036)

Choufani S, Shapiro JS, Susiarjo M, Butcher DT, Grafodatskaya D, Lou Y, Ferreira JC, Pinto D, Scherer SW, Shaffer LG et al. 2011 A novel approach identifies new differentially methylated regions (DMRs) associated with imprinted genes. Genome Research 21 465-476. (doi:10.1101/gr.111922.110)

Clapcott SJ, Peters J, Orban PC, Brambilla R \& Graham CF 2003 Two ENUinduced mutations in Rasgrf1 and early mouse growth retardation. Mammalian Genome 14 495-505. (doi:10.1007/s00335-002-2258-4) 
Clark L, Wei M, Cattoretti G, Mendelsohn C \& Tycko B 2002 The Tnfrh1 (Tnfrsf23) gene is weakly imprinted in several organs and expressed at the trophoblast-decidua interface. BMC Genetics 3 11. (doi:10.1186/14712156-3-11)

Coan PM, Conroy N, Burton GJ \& Ferguson-Smith AC 2006 Origin and characteristics of glycogen cells in the developing murine placenta. Developmental Dynamics 235 3280-3294. (doi:10.1002/dvdy.20981)

Coan PM, Vaughan OR, Sekita Y, Finn SL, Burton GJ, Constancia M \& Fowden AL 2010 Adaptations in placental phenotype support fetal growth during undernutrition of pregnant mice. Journal of Physiology 588 527-538. (doi:10.1113/jphysiol.2009.181214)

Constância $M$, Hemberger $M$, Hughes J, Dean W, Ferguson-Smith A, Fundele R, Stewart F, Kelsey G, Fowden A, Sibley C et al. 2002 Placentalspecific IGF-II is a major modulator of placental and fetal growth. Nature 417 945-948. (doi:10.1038/nature00819)

Dao D, Frank D, Qian N, O'Keefe D, Vosatka RJ, Walsh CP \& Tycko B 1998 IMPT1, an imprinted gene similar to polyspecific transporter and multi-drug resistance genes. Human Molecular Genetics 7 597-608. (doi:10.1093/hmg/7.4.597)

Davies W, Smith RJ, Kelsey G \& Wilkinson LS 2004 Expression patterns of the novel imprinted genes Nap1 15 and Peg13 and their non-imprinted host genes in the adult mouse brain. Gene Expression Patterns 4 741-747. (doi:10.1016/j.modgep.2004.03.008)

Davis E, Caiment F, Tordoir X, Cavaille J, Ferguson-Smith A, Cockett N, Georges M \& Charlier C 2005 RNAi-mediated allelic trans-interaction at the imprinted Rtl1/Peg11 locus. Current Biology 15 743-749. (doi:10.1016/j.cub.2005.02.060)

DeChiara TM, Efstratiadis A \& Robertson EJ 1990 A growth-deficiency phenotype in heterozygous mice carrying an insulin-like growth factor II gene disrupted by targeting. Nature 345 78-80. (doi:10.1038/345078a0)

DeChiara TM, Robertson EJ \& Efstratiadis A 1991 Parental imprinting of the mouse insulin-like growth factor II gene. Cell 64 849-859. (doi:10.1016/ 0092-8674(91)90513-X)

Deltour L, Montagutelli X, Guenet JL, Jami J \& Paldi A 1995 Tissue- and developmental stage-specific imprinting of the mouse proinsulin gene, Ins2. Developmental Biology 168 686-688. (doi:10.1006/dbio.1995.1114)

Deltour L, Vandamme J, Jouvenot Y, Duvillie B, Kelemen K, Schaerly P, Jami J \& Paldi A 2004 Differential expression and imprinting status of Ins1 and Ins2 genes in extraembryonic tissues of laboratory mice. Gene Expression Patterns 5 297-300. (doi:10.1016/j.modgep.2004.04.013)

Denda K, Nakao-Wakabayashi K, Okamoto N, Kitamura N, Ryu JY, Tagawa Y, Ichisaka T, Yamanaka S \& Komada M 2011 Nrk, an X-linked protein kinase in the germinal center kinase family, is required for placental development and fetoplacental induction of labor. Journal of Biological Chemistry 286 28802-28810. (doi:10.1074/jbc.M111.258160)

Dockery L, Gerfen J, Harview C, Rahn-Lee C, Horton R, Park Y \& Davis TL 2009 Differential methylation persists at the mouse Rasgrf1 DMR in tissues displaying monoallelic and biallelic expression. Epigenetics 4 $241-247$.

Engemann S, Strodicke M, Paulsen M, Franck O, Reinhardt R, Lane N, Reik W \& Walter J 2000 Sequence and functional comparison in the Beckwith-Wiedemann region: implications for a novel imprinting centre and extended imprinting. Human Molecular Genetics 9 2691-2706. (doi:10.1093/hmg/9.18.2691)

Esquiliano DR, Guo W, Liang L, Dikkes P \& Lopez MF 2009 Placental glycogen stores are increased in mice with $\mathrm{H} 19$ null mutations but not in those with insulin or IGF type 1 receptor mutations. Placenta $\mathbf{3 0}$ 693-699. (doi:10.1016/j.placenta.2009.05.004)

Ferguson-Smith AC \& Surani MA 2001 Imprinting and the epigenetic asymmetry between parental genomes. Science 293 1086-1089. (doi:10.1126/science.1064020)

Fitzpatrick GV, Soloway PD \& Higgins MJ 2002 Regional loss of imprinting and growth deficiency in mice with a targeted deletion of KvDMR1. Nature Genetics 32 426-431. (doi:10.1038/ng988)

Fortier AL, Lopes FL, Darricarrere N, Martel J \& Trasler JM 2008 Superovulation alters the expression of imprinted genes in the midgestation mouse placenta. Human Molecular Genetics 17 1653-1665. (doi:10.1093/hmg/ddn055)

Fowden AL, Coan PM, Angiolini E, Burton GJ \& Constancia M 2011 Imprinted genes and the epigenetic regulation of placental phenotype. Progress in Biophysics and Molecular Biology $106 \quad 281-288$. (doi:10.1016/j.pbiomolbio.2010.11.005)
Frank D, Mendelsohn CL, Ciccone E, Svensson K, Ohlsson R \& Tycko B 1999 A novel pleckstrin homology-related gene family defined by Ipl/Tssc3, TDAG51, and Tih1: tissue-specific expression, chromosomal location, and parental imprinting. Mammalian Genome 10 1150-1159. (doi:10.1007/s003359901182)

Frank D, Fortino W, Clark L, Musalo R, Wang W, Saxena A, Li CM, Reik W, Ludwig T \& Tycko B 2002 Placental overgrowth in mice lacking the imprinted gene Ipl. PNAS 99 7490-7495. (doi:10.1073/pnas.1220 39999)

Frankenberg S, Smith L, Greenfield A \& Zernicka-Goetz M 2007 Novel gene expression patterns along the proximo-distal axis of the mouse embryo before gastrulation. BMC Developmental Biology 78. (doi:10.1186/1471-213X-7-8)

Georgiades P, Watkins M, Surani MA \& Ferguson-Smith AC 2000 Parental origin-specific developmental defects in mice with uniparental disomy for chromosome 12. Development 127 4719-4728.

Georgiades P, Watkins M, Burton GJ \& Ferguson-Smith AC 2001 Roles for genomic imprinting and the zygotic genome in placental development. PNAS 98 4522-4527. (doi:10.1073/pnas.081540898)

Georgiades P, Ferguson-Smith AC \& Burton GJ 2002 Comparative developmental anatomy of the murine and human definitive placentae. Placenta 23 3-19. (doi:10.1053/plac.2001.0738)

Giddings SJ, King CD, Harman KW, Flood JF \& Carnaghi LR 1994 Allele specific inactivation of insulin 1 and 2, in the mouse yolk sac, indicates imprinting. Nature Genetics 6 310-313. (doi:10.1038/ng0394-310)

Gould TD \& Pfeifer K 1998 Imprinting of mouse Kvlqt1 is developmentally regulated. Human Molecular Genetics 7 483-487. (doi:10.1093/hmg/7. 3.483)

Gray TA, Saitoh S \& Nicholls RD 1999 An imprinted, mammalian bicistronic transcript encodes two independent proteins. PNAS 96 5616-5621. (doi:10.1073/pnas.96.10.5616)

Guillemot F, Nagy A, Auerbach A, Rossant J \& Joyner AL 1994 Essential role of Mash-2 in extraembryonic development. Nature 371 333-336. (doi:10.1038/371333a0)

Guillemot F, Caspary T, Tilghman SM, Copeland NG, Gilbert DJ, Jenkins NA, Anderson DJ, Joyner AL, Rossant J \& Nagy A 1995 Genomic imprinting of Mash2, a mouse gene required for trophoblast development. Nature Genetics 9 235-242. (doi:10.1038/ng0395-235)

Hagan JP, O'Neill BL, Stewart CL, Kozlov SV \& Croce CM 2009 At least ten genes define the imprinted Dlk1-Dio3 cluster on mouse chromosome 12qF1. PLoS ONE 4 e4352. (doi:10.1371/journal.pone.0004352)

Hagiwara Y, Hirai M, Nishiyama K, Kanazawa I, Ueda T, Sakaki Y \& Ito T 1997 Screening for imprinted genes by allelic message display: identification of a paternally expressed gene impact on mouse chromosome 18. PNAS 94 9249-9254. (doi:10.1073/pnas.94.17.9249)

Hatada I \& Mukai T 1995 Genomic imprinting of p57KIP2, a cyclindependent kinase inhibitor, in mouse. Nature Genetics 11 204-206. (doi:10.1038/ng1095-204)

Hatada I, Kitagawa K, Yamaoka T, Wang X, Arai Y, Hashido K, Ohishi S, Masuda J, Ogata J \& Mukai T 1995 Allele-specific methylation and expression of an imprinted U2af1-rs1 (SP2) gene. Nucleic Acids Research 23 36-41. (doi:10.1093/nar/23.1.36)

Hatada I, Morita S, Obata Y, Sotomaru Y, Shimoda M \& Kono T 2001 Identification of a new imprinted gene, Rian, on mouse chromosome 12 by fluorescent differential display screening. Journal of Biochemistry 130 187-190. (doi:10.1093/oxfordjournals.jbchem.a002971)

Hayashizaki Y, Shibata H, Hirotsune S, Sugino H, Okazaki Y, Sasaki N, Hirose K, Imoto H, Okuizumi H, Muramatsu M et al. 1994 Identification of an imprinted $\mathrm{U} 2 \mathrm{af}$ binding protein related sequence on mouse chromosome 11 using the RLGS method. Nature Genetics 6 33-40. (doi:10.1038/ng0194-33)

Hernandez A, Lyon GJ, Schneider MJ \& St Germain DL 1999 Isolation and characterization of the mouse gene for the type 3 iodothyronine deiodinase. Endocrinology 140 124-130. (doi:10.1210/en.140.1.124)

Hernandez A, Fiering S, Martinez E, Galton VA \& St Germain D 2002 The gene locus encoding iodothyronine deiodinase type 3 (Dio3) is imprinted in the fetus and expresses antisense transcripts. Endocrinology 143 4483-4486. (doi:10.1210/en.2002-220800)

Hershko A, Razin A \& Shemer R 1999 Imprinted methylation and its effect on expression of the mouse Zfp127 gene. Gene 234 323-327. (doi:10.1016/S0378-1119(99)00192-4) 
Hiby SE, Lough M, Keverne EB, Surani MA, Loke YW \& King A 2001 Paternal monoallelic expression of PEG3 in the human placenta. Human Molecular Genetics 10 1093-1100. (doi:10.1093/hmg/10.10.1093)

Higashimoto K, Soejima H, Yatsuki H, Joh K, Uchiyama M, Obata $Y$, Ono R, Wang Y, Xin Z, Zhu X et al. 2002 Characterization and imprinting status of OBPH1/Obph1 gene: implications for an extended imprinting domain in human and mouse. Genomics 80 575-584. (doi:10.1006/geno.2002.7006)

Hiura H, Sugawara A, Ogawa H, John RM, Miyauchi N, Miyanari $Y$, Horiike T, Li Y, Yaegashi N, Sasaki H et al. 2010 A tripartite paternally methylated region within the Gpr1-Zdbf2 imprinted domain on mouse chromosome 1 identified by meDIP-on-chip. Nucleic Acids Research $\mathbf{3 8}$ 4929-4945. (doi:10.1093/nar/gkq200)

Hoshiya H, Meguro M, Kashiwagi A, Okita C \& Oshimura M 2003 Calcr, a brain-specific imprinted mouse calcitonin receptor gene in the imprinted cluster of the proximal region of chromosome 6 . Journal of Human Genetics 48 208-211. (doi:10.1007/s10038-003-0006-6)

Hu JF, Oruganti H, Vu TH \& Hoffman AR 1998 Tissue-specific imprinting of the mouse insulin-like growth factor II receptor gene correlates with differential allele-specific DNA methylation. Molecular Endocrinology 12 220-232. (doi:10.1210/me.12.2.220)

Hudson QJ, Kulinski TM, Huetter SP \& Barlow DP 2010 Genomic imprinting mechanisms in embryonic and extraembryonic mouse tissues. Heredity 105 45-56. (doi:10.1038/hdy.2010.23)

Hudson QJ, Seidl Cl, Kulinski TM, Huang R, Warczok KE, Bittner R, Bartolomei MS \& Barlow DP 2011 Extra-embryonic-specific imprinted expression is restricted to defined lineages in the post-implantation embryo. Developmental Biology 353 420-431. (doi:10.1016/j.ydbio. 2011.02.017)

Iglesias-Platas I, Martin-Trujillo A, Cirillo D, Court F, Guillaumet-Adkins A, Camprubi C, Bourc'his D, Hata K, Feil R, Tartaglia G et al. 2012 Characterization of novel paternal ncRNAs at the Plagl1 locus, including Hymai, predicted to interact with regulators of active chromatin. PLoS ONE 7 e38907. (doi:10.1371/journal.pone.0038907)

Ishikawa H, Rattigan A, Fundele R \& Burgoyne PS 2003 Effects of sex chromosome dosage on placental size in mice. Biology of Reproduction 69 483-488. (doi:10.1095/biolreprod.102.012641)

Itier JM, Tremp GL, Leonard JF, Multon MC, Ret G, Schweighoffer F, Tocque B, Bluet-Pajot MT, Cormier V \& Dautry F 1998 Imprinted gene in postnatal growth role. Nature 393 125-126. (doi:10.1038/30120)

Itoh M, Yoshida Y, Nishida K, Narimatsu M, Hibi M \& Hirano T 2000 Role of Gab1 in heart, placenta, and skin development and growth factorand cytokine-induced extracellular signal-regulated kinase mitogenactivated protein kinase activation. Molecular and Cellular Biology 20 3695-3704. (doi:10.1128/MCB.20.10.3695-3704.2000)

Jackman SM, Kong X \& Fant ME 2012 Plac1 (placenta-specific 1) is essential for normal placental and embryonic development. Molecular Reproduction and Development 79 564-572. (doi:10.1002/mrd.22062)

John R \& Hemberger M 2012 A placenta for life. Reproductive Biomedicine Online 25 5-11. (doi:10.1016/j.rbmo.2012.03.018)

Johnson DR 1974 Hairpin-tail: a case of post-reductional gene action in the mouse egg. Genetics 76 795-805.

Jong MT, Carey AH, Caldwell KA, Lau MH, Handel MA, Driscoll DJ, Stewart CL, Rinchik EM \& Nicholls RD 1999 Imprinting of a RING zincfinger encoding gene in the mouse chromosome region homologous to the Prader-Willi syndrome genetic region. Human Molecular Genetics 8 795-803. (doi:10.1093/hmg/8.5.795)

Jonker JW, Wagenaar E, Van Eijl S \& Schinkel AH 2003 Deficiency in the organic cation transporters 1 and 2 (Oct1/Oct2 [Slc22a1/Slc22a2]) in mice abolishes renal secretion of organic cations. Molecular and Cellular Biology 23 7902-7908. (doi:10.1128/MCB.23.21.7902-7908. 2003)

Kagitani F, Kuroiwa Y, Wakana S, Shiroishi T, Miyoshi N, Kobayashi S, Nishida M, Kohda T, Kaneko-Ishino T \& Ishino F 1997 Peg5/Neuronatin is an imprinted gene located on sub-distal chromosome 2 in the mouse. Nucleic Acids Research 25 3428-3432. (doi:10.1093/nar/25.17.3428)

Kaneko-Ishino T, Kuroiwa Y, Miyoshi N, Kohda T, Suzuki R, Yokoyama M, Viville S, Barton SC, Ishino F \& Surani MA 1995 Peg1/Mest imprinted gene on chromosome 6 identified by cDNA subtraction hybridization. Nature Genetics 11 52-59. (doi:10.1038/ng0995-52)
Kashiwagi A, Meguro M, Hoshiya H, Haruta M, Ishino F, Shibahara T \& Oshimura M 2003 Predominant maternal expression of the mouse Atp10c in hippocampus and olfactory bulb. Journal of Human Genetics 48 194-198. (doi:10.1007/s10038-003-0009-3)

Kato MV, Ikawa Y, Hayashizaki Y \& Shibata H 1998 Paternal imprinting of mouse serotonin receptor $2 \mathrm{~A}$ gene $\mathrm{Htr} 2$ in embryonic eye: a conserved imprinting regulation on the RB/Rb locus. Genomics 47 146-148. (doi:10.1006/geno.1997.5089)

Kaufman MH, Barton SC \& Surani MA 1977 Normal postimplantation development of mouse parthenogenetic embryos to the forelimb bud stage. Nature 265 53-55. (doi:10.1038/265053a0)

Kawase T, Ohki R, Shibata T, Tsutsumi S, Kamimura N, Inazawa J, Ohta T, Ichikawa H, Aburatani H, Tashiro $\mathbf{F}$ et al. $2009 \mathrm{PH}$ domain-only protein PHLDA3 is a p53-regulated repressor of Akt. Cell 136 535-550. (doi:10.1016/j.cell.2008.12.002)

Keniry A, Oxley D, Monnier P, Kyba M, Dandolo L, Smits G \& Reik W 2012 The H19 lincRNA is a developmental reservoir of miR-675 that suppresses growth and Igf1r. Nature Cell Biology 14 659-665. (doi:10.1038/ncb2521)

Khatib H 2007 Is it genomic imprinting or preferential expression? BioEssays 29 1022-1028. (doi:10.1002/bies.20637)

Kikyo N, Williamson CM, John RM, Barton SC, Beechey CV, Ball ST, Cattanach BM, Surani MA \& Peters J 1997 Genetic and functional analysis of neuronatin in mice with maternal or paternal duplication of distal Chr 2. Developmental Biology 190 66-77. (doi:10.1006/dbio. 1997.8681)

Kim J, Lu X \& Stubbs L 1999 Zim1, a maternally expressed mouse Kruppeltype zinc-finger gene located in proximal chromosome 7 . Human Molecular Genetics 8 847-854. (doi:10.1093/hmg/8.5.847)

Kim J, Noskov VN, Lu X, Bergmann A, Ren X, Warth T, Richardson P, Kouprina N \& Stubbs L 2000 Discovery of a novel, paternally expressed ubiquitin-specific processing protease gene through comparative analysis of an imprinted region of mouse chromosome 7 and human chromosome 19q13.4. Genome Research 10 1138-1147. (doi:10.1101/ gr.10.8.1138)

Kim J, Bergmann A, Wehri E, Lu X \& Stubbs L 2001 Imprinting and evolution of two Kruppel-type zinc-finger genes, ZIM3 and ZNF264, located in the PEG3/USP29 imprinted domain. Genomics 77 91-98. (doi:10.1006/geno.2001.6621)

Kim J, Bergmann A, Lucas S, Stone R \& Stubbs L 2004 Lineage-specific imprinting and evolution of the zinc-finger gene ZIM2. Genomics $\mathbf{8 4}$ 47-58. (doi:10.1016/j.ygeno.2004.02.007)

Kobayashi S, Kohda T, Ichikawa H, Ogura A, Ohki M, Kaneko-Ishino T \& Ishino F 2002 Paternal expression of a novel imprinted gene, Peg12/Frat3, in the mouse $7 \mathrm{C}$ region homologous to the Prader-Willi syndrome region. Biochemical and Biophysical Research Communications 290 403-408. (doi:10.1006/bbrc.2001.6160)

Kobayashi H, Yamada K, Morita S, Hiura H, Fukuda A, Kagami M, Ogata T, Hata K, Sotomaru Y \& Kono T 2009 Identification of the mouse paternally expressed imprinted gene Zdbf2 on chromosome 1 and its imprinted human homolog ZDBF2 on chromosome 2. Genomics 93 461-472. (doi:10.1016/j.ygeno.2008.12.012)

Kozlov SV, Bogenpohl JW, Howell MP, Wevrick R, Panda S, Hogenesch JB, Muglia LJ, Van Gelder RN, Herzog ED \& Stewart CL 2007 The imprinted gene Magel2 regulates normal circadian output. Nature Genetics 39 1266-1272. (doi:10.1038/ng2114)

Kromer B, Finkenzeller D, Wessels J, Dveksler G, Thompson J \& Zimmermann W 1996 Coordinate expression of splice variants of the murine pregnancy-specific glycoprotein (PSG) gene family during placental development. European Journal of Biochemistry 242 280-287. (doi:10.1111/j.1432-1033.1996.0280r.x)

Kuroiwa Y, Kaneko-Ishino T, Kagitani F, Kohda T, Li LL, Tada M, Suzuki R, Yokoyama M, Shiroishi T, Wakana S et al. 1996 Peg3 imprinted gene on proximal chromosome 7 encodes for a zinc finger protein. Nature Genetics 12 186-190. (doi:10.1038/ng0296-186)

Kuzmin A, Han Z, Golding MC, Mann MR, Latham KE \& Varmuza S 2008 The PcG gene Sfmbt2 is paternally expressed in extraembryonic tissues. Gene Expression Patterns 8 107-116. (doi:10.1016/j.modgep.2007.09.005)

Labialle S, Croteau S, Belanger V, McMurray EN, Ruan X, Moussette S, Jonnaert M, Schmidt JV, Cermakian N \& Naumova AK 2008 
Novel imprinted transcripts from the Dlk1-Gt12 intergenic region, Mico1 and Mico1os, show circadian oscillations. Epigenetics 3 322-329. (doi:10.4161/epi.3.6.7109)

Lau MM, Stewart CE, Liu Z, Bhatt H, Rotwein P \& Stewart CL 1994 Loss of the imprinted IGF2/cation-independent mannose 6-phosphate receptor results in fetal overgrowth and perinatal lethality. Genes and Development 8 2953-2963. (doi:10.1101/gad.8.24.2953)

Lee YJ, Park CW, Hahn Y, Park J, Lee J, Yun JH, Hyun B \& Chung JH 2000 Mit1/Lb9 and Copg2, new members of mouse imprinted genes closely linked to Peg1/Mest(1). FEBS Letters 472 230-234. (doi:10.1016/S00145793(00)01461-7)

Lefebvre L 2012 The placental imprintome and imprinted gene function in the trophoblast glycogen cell lineage. Reproductive Biomedicine Online 25 44-57. (doi:10.1016/j.rbmo.2012.03.019)

Lefebvre L, Viville S, Barton SC, Ishino F, Keverne EB \& Surani MA 1998 Abnormal maternal behaviour and growth retardation associated with loss of the imprinted gene Mest. Nature Genetics 20 163-169. (doi:10.1038/2464)

Lefebvre L, Mar L, Bogutz A, Oh-McGinnis R, Mandegar MA, Paderova J, Gertsenstein M, Squire JA \& Nagy A 2009 The interval between Ins2 and Ascl2 is dispensable for imprinting centre function in the murine Beckwith-Wiedemann region. Human Molecular Genetics 18 4255-4267. (doi:10.1093/hmg/ddp379)

Leff SE, Brannan CI, Reed ML, Ozcelik T, Francke U, Copeland NG \& Jenkins NA 1992 Maternal imprinting of the mouse Snrpn gene and conserved linkage homology with the human Prader-Willi syndrome region. Nature Genetics 2 259-264. (doi:10.1038/ng1292-259)

Leighton PA, Ingram RS, Eggenschwiler J, Efstratiadis A \& Tilghman SM 1995 Disruption of imprinting caused by deletion of the $\mathrm{H} 19$ gene region in mice. Nature 375 34-39. (doi:10.1038/375034a0)

Lerchner W \& Barlow DP 1997 Paternal repression of the imprinted mouse Igf2r locus occurs during implantation and is stable in all tissues of the post-implantation mouse embryo. Mechanisms of Development $\mathbf{6 1}$ 141-149. (doi:10.1016/S0925-4773(96)00630-2)

Li Y \& Behringer RR 1998 Esx1 is an X-chromosome-imprinted regulator of placental development and fetal growth. Nature Genetics 20 309-311. (doi:10.1038/3129)

Li Y, Lemaire P \& Behringer RR 1997 Esx1, a novel X chromosomelinked homeobox gene expressed in mouse extraembryonic tissues and male germ cells. Developmental Biology 188 85-95. (doi:10.1006/dbio. 1997.8640)

Li L, Keverne EB, Aparicio SA, Ishino F, Barton SC \& Surani MA 1999 Regulation of maternal behavior and offspring growth by paternally expressed Peg3. Science 284 330-333. (doi:10.1126/science.284.5412.330)

Lin SP, Youngson N, Takada S, Seitz H, Reik W, Paulsen M, Cavaille J \& Ferguson-Smith AC 2003 Asymmetric regulation of imprinting on the maternal and paternal chromosomes at the Dlk1-Gt|2 imprinted cluster on mouse chromosome 12. Nature Genetics 35 97-102. (doi:10.1038/ ng1233)

Liu J, Yu S, Litman D, Chen W \& Weinstein LS 2000 Identification of a methylation imprint mark within the mouse Gnas locus. Molecular and Cellular Biology 20 5808-5817. (doi:10.1128/MCB.20.16.5808-5817.2000)

Lopez MF, Dikkes P, Zurakowski D \& Villa-Komaroff L 1996 Insulin-like growth factor II affects the appearance and glycogen content of glycogen cells in the murine placenta. Endocrinology 137 2100-2108. (doi:10.1210/en.137.5.2100)

Ludwig T, Eggenschwiler J, Fisher P, D'Ercole AJ, Davenport ML \& Efstratiadis A 1996 Mouse mutants lacking the type 2 IGF receptor (IGF2R) are rescued from perinatal lethality in Igf2 and Igf1r null backgrounds. Developmental Biology 177 517-535. (doi:10.1006/dbio. 1996.0182)

Lyle R, Watanabe D, te Vruchte D, Lerchner W, Smrzka OW, Wutz A, Schageman J, Hahner L, Davies C \& Barlow DP 2000 The imprinted antisense RNA at the Igf2r locus overlaps but does not imprint Mas1. Nature Genetics 25 19-21. (doi:10.1038/75546)

MacDonald HR \& Wevrick R 1997 The necdin gene is deleted in Prader-Willi syndrome and is imprinted in human and mouse. Human Molecular Genetics 6 1873-1878. (doi:10.1093/hmg/6.11.1873)

Mancini-DiNardo D, Steele SJ, Ingram RS \& Tilghman SM 2003 A differentially methylated region within the gene Kcnq1 functions as an imprinted promoter and silencer. Human Molecular Genetics 12 283-294. (doi:10.1093/hmg/ddg024)
Mancini-Dinardo D, Steele SJ, Levorse JM, Ingram RS \& Tilghman SM 2006 Elongation of the Kcnq1 ot1 transcript is required for genomic imprinting of neighboring genes. Genes and Development 20 1268-1282. (doi:10.1101/gad.1416906)

Mayer W, Hemberger M, Frank HG, Grummer R, Winterhager E, Kaufmann P \& Fundele R 2000 Expression of the imprinted genes MEST/Mest in human and murine placenta suggests a role in angiogenesis. Developmental Dynamics 217 1-10. (doi:10.1002/(SICl)10970177(200001)217:1 < 1::AID-DVDY1 > 3.0.CO;2-4)

McGrath J \& Solter D 1984 Completion of mouse embryogenesis requires both the maternal and paternal genomes. Cell 37 179-183. (doi:10.1016/0092-8674(84)90313-1)

McLaughlin KJ, Szabo P, Haegel H \& Mann JR 1996 Mouse embryos with paternal duplication of an imprinted chromosome 7 region die at midgestation and lack placental spongiotrophoblast. Development 122 265-270.

McLaughlin KJ, Solter D \& Mann J 1997 Developmental consequences of two paternal copies of imprinted chromosome region distal 7 in mice. Journal of Cellular Physiology 173 242-246. (doi:10.1002/(SICl)10974652(199711)173:2 <242::AID-JCP29>3.0.CO;2-G)

Menheniott TR, Woodfine K, Schulz R, Wood AJ, Monk D, Giraud AS, Baldwin HS, Moore GE \& Oakey RJ 2008 Genomic imprinting of Dopa decarboxylase in heart and reciprocal allelic expression with neighboring Grb10. Molecular and Cellular Biology 28 386-396. (doi:10.1128/ MCB.00862-07)

Miura K, Kishino T, Li E, Webber H, Dikkes P, Holmes GL \& Wagstaff J 2002 Neurobehavioral and electroencephalographic abnormalities in Ube3a maternal-deficient mice. Neurobiological Disorders 9 149-159.

Miyoshi N, Kuroiwa Y, Kohda T, Shitara H, Yonekawa H, Kawabe T, Hasegawa H, Barton SC, Surani MA, Kaneko-Ishino T et al. 1998 Identification of the Meg1/Grb10 imprinted gene on mouse proximal chromosome 11, a candidate for the Silver-Russell syndrome gene. PNAS 95 1102-1107. (doi:10.1073/pnas.95.3.1102)

Mizuno Y, Sotomaru Y, Katsuzawa Y, Kono T, Meguro M, Oshimura M, Kawai J, Tomaru Y, Kiyosawa H, Nikaido I et al. 2002 Asb4, Ata3, and Dcn are novel imprinted genes identified by high-throughput screening using RIKEN cDNA microarray. Biochemical and Biophysical Research Communications 290 1499-1505. (doi:10.1006/bbrc.2002.6370)

Mochizuki A, Takeda Y \& Iwasa Y 1996 The evolution of genomic imprinting. Genetics 144 1283-1295.

Monk D, Wagschal A, Arnaud P, Muller PS, Parker-Katiraee L, Bourc'his D, Scherer SW, Feil R, Stanier P \& Moore GE 2008 Comparative analysis of human chromosome $7 q 21$ and mouse proximal chromosome 6 reveals a placental-specific imprinted gene, TFPI2/Tfpi2, which requires EHMT2 and EED for allelic-silencing. Genome Research 18 1270-1281. (doi:10.1101/gr.077115.108)

Moore T, Constância M, Zubair M, Bailleul B, Feil R, Sasaki H \& Reik W 1997 Multiple imprinted sense and antisense transcripts, differential methylation and tandem repeats in a putative imprinting control region upstream of mouse Igf2. PNAS 94 12509-12514. (doi:10.1073/pnas.94. 23.12509)

Morgan DO, Edman JC, Standring DN, Fried VA, Smith MC, Roth RA \& Rutter WJ 1987 Insulin-like growth factor II receptor as a multifunctional binding protein. Nature 329 301-307. (doi:10.1038/329301a0)

Nakabayashi K, Makino S, Minagawa S, Smith AC, Bamforth JS, Stanier P, Preece M, Parker-Katiraee L, Paton T, Oshimura M et al. 2004 Genomic imprinting of PPP1R9A encoding neurabin I in skeletal muscle and extra-embryonic tissues. Journal of Medical Genetics 41 601-608. (doi:10.1136/jmg.2003.014142)

Nie G, Li Y, He H, Findlay JK \& Salamonsen LA $2006 \mathrm{HtrA3}$, a serine protease possessing an IGF-binding domain, is selectively expressed at the maternal-fetal interface during placentation in the mouse. Placenta 27 491-501. (doi:10.1016/j.placenta.2005.03.009)

Nomura T, Kimura M, Horii T, Morita S, Soejima H, Kudo S \& Hatada I 2008 MeCP2-dependent repression of an imprinted miR-184 released by depolarization. Human Molecular Genetics 17 1192-1199. (doi:10.1093/hmg/ddn011)

Novitskaya T, Baserga M \& de Caestecker MP 2011 Organ-specific defects in insulin-like growth factor and insulin receptor signaling in late gestational asymmetric intrauterine growth restriction in Cited 1 mutant mice. Endocrinology 152 2503-2516. (doi:10.1210/en.2010-1385) 
Oakey RJ, Matteson PG, Litwin S, Tilghman SM \& Nussbaum RL 1995 Nondisjunction rates and abnormal embryonic development in a mouse cross between heterozygotes carrying a $(7,18)$ robertsonian translocation chromosome. Genetics 141 667-674.

Oh-McGinnis R, Bogutz AB \& Lefebvre L 2011 Partial loss of Ascl2 function affects all three layers of the mature placenta and causes intrauterine growth restriction. Developmental Biology 351 277-286. (doi:10.1016/ j.ydbio.2011.01.008)

Okae H, Hiura H, Nishida Y, Funayama R, Tanaka S, Chiba H, Yaegashi N, Nakayama K, Sasaki H \& Arima T 2012 Re-investigation and RNA sequencing-based identification of genes with placenta-specific imprinted expression. Human Molecular Genetics 21 548-558. (doi:10.1093/hmg/ddr488)

Ono R, Shiura H, Aburatani H, Kohda T, Kaneko-Ishino T \& Ishino F 2003 Identification of a large novel imprinted gene cluster on mouse proximal chromosome 6. Genome Research 13 1696-1705. (doi:10.1101/gr. 906803)

Ono R, Nakamura K, Inoue K, Naruse M, Usami T, Wakisaka-Saito N, Hino T, Suzuki-Migishima R, Ogonuki N, Miki H et al. 2006 Deletion of Peg10, an imprinted gene acquired from a retrotransposon, causes early embryonic lethality. Nature Genetics 38 101-106. (doi:10.1038/ ng1699)

Parker-Katiraee L, Carson AR, Yamada T, Arnaud P, Feil R, Abu-Amero SN, Moore GE, Kaneda M, Perry GH, Stone AC et al. 2007 Identification of the imprinted KLF14 transcription factor undergoing human-specific accelerated evolution. PLoS Genetics 3 e65. (doi:10.1371/journal.pgen. 0030065)

Peters J, Wroe SF, Wells CA, Miller HJ, Bodle D, Beechey CV, Williamson CM \& Kelsey G 1999 A cluster of oppositely imprinted transcripts at the Gnas locus in the distal imprinting region of mouse chromosome 2. PNAS 96 3830-3835. (doi:10.1073/pnas.96.7.3830)

Pfeifer K 2000 Mechanisms of genomic imprinting. American Journal of Human Genetics 67 777-787. (doi:10.1086/303101)

Piras G, El Kharroubi A, Kozlov S, Escalante-Alcalde D, Hernandez L, Copeland NG, Gilbert DJ, Jenkins NA \& Stewart CL 2000 Zac1 (Lot1), a potential tumor suppressor gene, and the gene for epsilon-sarcoglycan are maternally imprinted genes: identification by a subtractive screen of novel uniparental fibroblast lines. Molecular and Cellular Biology 20 3308-3315. (doi:10.1128/MCB.20.9.3308-3315.2000)

Plass C, Shibata H, Kalcheva I, Mullins L, Kotelevtseva N, Mullins J, Kato R, Sasaki H, Hirotsune S, Okazaki Y et al. 1996 Identification of Grf1 on mouse chromosome 9 as an imprinted gene by RLGS-M. Nature Genetics 14 106-109. (doi:10.1038/ng0996-106)

de la Puente A, Hall J, Wu YZ, Leone G, Peters J, Yoon BJ, Soloway P \& Plass C 2002 Structural characterization of Rasgrf1 and a novel linked imprinted locus. Gene 291 287-297. (doi:10.1016/S0378-1119(02) 00601-7)

Qian N, Frank D, O'Keefe D, Dao D, Zhao L, Yuan L, Wang Q, Keating M, Walsh C \& Tycko B 1997 The IPL gene on chromosome 11p15.5 is imprinted in humans and mice and is similar to TDAG51, implicated in Fas expression and apoptosis. Human Molecular Genetics 6 2021-2029. (doi:10.1093/hmg/6.12.2021)

Redline RW, Chernicky CL, Tan HQ, Ilan J \& Ilan J 1993 Differential expression of insulin-like growth factor-II in specific regions of the late (post day 9.5) murine placenta. Molecular Reproduction and Development 36 121-129. (doi:10.1002/mrd.1080360202)

Reik W \& Walter J 2001 Genomic imprinting: parental influence on the genome. Nature Reviews. Genetics 2 21-32. (doi:10.1038/35047554)

Relaix F, Weng X, Marazzi G, Yang E, Copeland N, Jenkins N, Spence SE \& Sassoon D 1996 Pw1, a novel zinc finger gene implicated in the myogenic and neuronal lineages. Developmental Biology 177 383-396. (doi:10.1006/dbio.1996.0172)

Rentsendorj A, Mohan S, Szabo P \& Mann JR 2010 A genomic imprinting defect in mice traced to a single gene. Genetics 186 917-927. (doi:10. 1534/genetics.110.118802)

da Rocha ST, Tevendale M, Knowles E, Takada S, Watkins M \& FergusonSmith AC 2007 Restricted co-expression of Dlk1 and the reciprocally imprinted non-coding RNA. Gt12: implications for cis-acting control. Developmental Biology 306 810-823. (doi:10.1016/j.ydbio.2007.02.043)

Rodriguez TA, Sparrow DB, Scott AN, Withington SL, Preis JI, Michalicek J, Clements M, Tsang TE, Shioda T, Beddington RS et al.
2004 Cited 1 is required in trophoblasts for placental development and for embryo growth and survival. Molecular and Cellular Biology 24 228-244. (doi:10.1128/MCB.24.1.228-244.2004)

Rossant J \& Cross JC 2001 Placental development: lessons from mouse mutants. Nature Reviews. Genetics 2 538-548. (doi:10.1038/35080570)

Rossant J, Guillemot F, Tanaka M, Latham K, Gertenstein M \& Nagy A 1998 Mash2 is expressed in oogenesis and preimplantation development but is not required for blastocyst formation. Mechanisms of Development 73 183-191. (doi:10.1016/S0925-4773(98)00051-3)

Ruf N, Bahring S, Galetzka D, Pliushch G, Luft FC, Nurnberg P, Haaf T, Kelsey G \& Zechner U 2007 Sequence-based bioinformatic prediction and QUASEP identify genomic imprinting of the KCNK9 potassium channel gene in mouse and human. Human Molecular Genetics 16 2591-2599. (doi:10.1093/hmg/ddm216)

Sachs M, Brohmann H, Zechner D, Muller T, Hulsken J, Walther I, Schaeper U, Birchmeier C \& Birchmeier W 2000 Essential role of Gab1 for signaling by the c-Met receptor in vivo. Journal of Cell Biology $\mathbf{1 5 0}$ 1375-1384. (doi:10.1083/jcb.150.6.1375)

Salas M, John R, Saxena A, Barton S, Frank D, Fitzpatrick G, Higgins MJ \& Tycko B 2004 Placental growth retardation due to loss of imprinting of Phlda2. Mechanisms of Development 121 1199-1210. (doi:10.1016/ j.mod.2004.05.017)

Sandell LL, Guan XJ, Ingram R \& Tilghman SM 2003 Gatm, a creatine synthesis enzyme, is imprinted in mouse placenta. PNAS $\mathbf{1 0 0}$ 4622-4627. (doi:10.1073/pnas.0230424100)

Sandovici I, Hoelle K, Angiolini E \& Constancia M 2012 Placental adaptations to the maternal-fetal environment: implications for fetal growth and developmental programming. Reproductive Biomedicine Online 25 68-89. (doi:10.1016/j.rbmo.2012.03.017)

de los Santos T, Schweizer J, Rees CA \& Francke U 2000 Small evolutionarily conserved RNA, resembling C/D box small nucleolar RNA, is transcribed from PWCR1, a novel imprinted gene in the PraderWilli deletion region, which Is highly expressed in brain. American Journal of Human Genetics 67 1067-1082. (doi:10.1086/303106)

Sasaki H, Ferguson-Smith AC, Shum AS, Barton SC \& Surani MA 1995 Temporal and spatial regulation of $\mathrm{H} 19$ imprinting in normal and uniparental mouse embryos. Development 121 4195-4202.

Schaeper U, Vogel R, Chmielowiec J, Huelsken J, Rosario M \& Birchmeier W 2007 Distinct requirements for Gab1 in Met and EGF receptor signaling in vivo. PNAS 104 15376-15381. (doi:10.1073/pnas. 0702555104)

Schmidt JV, Matteson PG, Jones BK, Guan XJ \& Tilghman SM 2000 The Dlk1 and Gtl2 genes are linked and reciprocally imprinted. Genes and Development 14 1997-2002.

Schulz R, Menheniott TR, Woodfine K, Wood AJ, Choi JD \& Oakey RJ 2006 Chromosome-wide identification of novel imprinted genes using microarrays and uniparental disomies. Nucleic Acids Research 34 e88. (doi:10.1093/nar/gkl461)

Schulz R, McCole RB, Woodfine K, Wood AJ, Chahal M, Monk D, Moore GE \& Oakey RJ 2009 Transcript- and tissue-specific imprinting of a tumour suppressor gene. Human Molecular Genetics 18 118-127. (doi:10.1093/hmg/ddn322)

Searle AG \& Beechey CV 1990 Genome imprinting phenomena on mouse chromosome 7. Genetical Research 56 237-244. (doi:10.1017/S00 16672300035333)

Seitz H, Youngson N, Lin SP, Dalbert S, Paulsen M, Bachellerie JP, Ferguson-Smith AC \& Cavaille J 2003 Imprinted microRNA genes transcribed antisense to a reciprocally imprinted retrotransposon-like gene. Nature Genetics 34 261-262. (doi:10.1038/ng1171)

Sekita Y, Wagatsuma H, Nakamura K, Ono R, Kagami M, Wakisaka N, Hino T, Suzuki-Migishima R, Kohda T, Ogura A et al. 2008 Role of retrotransposon-derived imprinted gene, Rtl1, in the feto-maternal interface of mouse placenta. Nature Genetics 40 243-248. (doi:10.1038/ng.2007.51)

Shi W, van den Hurk JA, Alamo-Bethencourt V, Mayer W, Winkens HJ, Ropers HH, Cremers FP \& Fundele R 2004 Choroideremia gene product affects trophoblast development and vascularization in mouse extraembryonic tissues. Developmental Biology 272 53-65. (doi:10.1016/j. ydbio.2004.04.016)

Shiura H, Nakamura K, Hikichi T, Hino T, Oda K, Suzuki-Migishima R, Kohda T, Kaneko-ishino T \& Ishino F 2009 Paternal deletion of Meg1/Grb10 DMR causes maternalization of the Meg1/Grb10 cluster 
in mouse proximal chromosome 11 leading to severe pre- and postnatal growth retardation. Human Molecular Genetics 18 1424-1438. (doi:10.1093/hmg/ddp049)

Simmons DG \& Cross JC 2005 Determinants of trophoblast lineage and cell subtype specification in the mouse placenta. Developmental Biology 284 12-24. (doi:10.1016/j.ydbio.2005.05.010)

Simmons DG, Fortier AL \& Cross JC 2007 Diverse subtypes and developmental origins of trophoblast giant cells in the mouse placenta. Developmental Biology 304 567-578. (doi:10.1016/j.ydbio.2007.01.009)

Simmons DG, Natale DR, Begay V, Hughes M, Leutz A \& Cross JC 2008a Early patterning of the chorion leads to the trilaminar trophoblast cell structure in the placental labyrinth. Development 135 2083-2091. (doi:10.1242/dev.020099)

Simmons DG, Rawn S, Davies A, Hughes M \& Cross JC 2008b Spatial and temporal expression of the 23 murine prolactin/placental lactogenrelated genes is not associated with their position in the locus. BMC Genomics 9 352. (doi:10.1186/1471-2164-9-352)

Singh H, Makino SI, Endo Y \& Nie G 2010 Inhibition of HTRA3 stimulates trophoblast invasion during human placental development. Placenta $\mathbf{3 1}$ 1085-1092. (doi:10.1016/j.placenta.2010.10.003)

Singh H, Endo Y \& Nie G 2011 Decidual HtrA3 negatively regulates trophoblast invasion during human placentation. Human Reproduction 26 748-757. (doi:10.1093/humrep/der019)

Smilinich NJ, Day CD, Fitzpatrick GV, Caldwell GM, Lossie AC, Cooper PR, Smallwood AC, Joyce JA, Schofield PN, Reik W et al. 1999 A maternally methylated CpG island in KvLQT1 is associated with an antisense paternal transcript and loss of imprinting in Beckwith-Wiedemann syndrome. PNAS 96 8064-8069. (doi:10.1073/pnas.96.14.8064)

Smith RJ, Dean W, Konfortova G \& Kelsey G 2003 Identification of novel imprinted genes in a genome-wide screen for maternal methylation. Genome Research 13 558-569. (doi:10.1101/gr.781503)

Spengler D, Villalba M, Hoffmann A, Pantaloni C, Houssami S, Bockaert J \& Journot L 1997 Regulation of apoptosis and cell cycle arrest by Zac1, a novel zinc finger protein expressed in the pituitary gland and the brain. EMBO Journal 16 2814-2825. (doi:10.1093/emboj/16.10.2814)

Sunahara S, Nakamura K, Nakao K, Gondo Y, Nagata Y \& Katsuki M 2000 The oocyte-specific methylated region of the U2afbp-rs/U2af1-rs1 gene is dispensable for its imprinted methylation. Biochemical and Biophysical Research Communications 268 590-595. (doi:10.1006/bbrc. 2000.2189)

Surani MA \& Barton SC 1983 Development of gynogenetic eggs in the mouse: implications for parthenogenetic embryos. Science 222 1034-1036. (doi:10.1126/science.6648518)

Surani MA, Barton SC \& Norris ML 1986 Nuclear transplantation in the mouse: heritable differences between parental genomes after activation of the embryonic genome. Cell 45 127-136. (doi:10.1016/00928674(86)90544-1)

Svensson K, Mattsson R, James TC, Wentzel P, Pilartz M, MacLaughlin J, Miller SJ, Olsson T, Eriksson UJ \& Ohlsson R 1998 The paternal allele of the $\mathrm{H} 19$ gene is progressively silenced during early mouse development: the acetylation status of histones may be involved in the generation of variegated expression patterns. Development 125 61-69.

Takagi N \& Sasaki M 1975 Preferential inactivation of the paternally derived $X$ chromosome in the extraembryonic membranes of the mouse. Nature 256 640-642. (doi:10.1038/256640a0)

Takahashi K, Kobayashi T \& Kanayama N 2000 p57(Kip2) regulates the proper development of labyrinthine and spongiotrophoblasts. Molecular Human Reproduction 6 1019-1025. (doi:10.1093/molehr/6. 11.1019)

Tanaka M, Gertsenstein M, Rossant J \& Nagy A 1997 Mash2 acts cell autonomously in mouse spongiotrophoblast development. Developmental Biology 190 55-65. (doi:10.1006/dbio.1997.8685)

Tanaka M, Puchyr M, Gertsenstein M, Harpal K, Jaenisch R, Rossant J \& Nagy A 1999 Parental origin-specific expression of Mash2 is established at the time of implantation with its imprinting mechanism highly resistant to genome-wide demethylation. Mechanisms of Development 87 129-142. (doi:10.1016/S0925-4773(99)00158-6)

Tevendale M, Watkins M, Rasberry C, Cattanach B \& Ferguson-Smith AC 2006 Analysis of mouse conceptuses with uniparental duplication/ deficiency for distal chromosome 12: comparison with chromosome 12 uniparental disomy and implications for genomic imprinting. Cytogenetic and Genome Research 113 215-222. (doi:10.1159/000090835)
Tierling S, Gasparoni G, Youngson N \& Paulsen M 2009 The Begain gene marks the centromeric boundary of the imprinted region on mouse chromosome 12. Mammalian Genome 20 699-710. (doi:10.1007/ s00335-009-9205-6)

Tsai CE, Lin SP, Ito M, Takagi N, Takada S \& Ferguson-Smith AC 2002 Genomic imprinting contributes to thyroid hormone metabolism in the mouse embryo. Current Biology 12 1221-1226. (doi:10.1016/S09609822(02)00951-X)

Tunster SJ, Tycko B \& John RM 2010 The imprinted Phlda2 gene regulates extraembryonic energy stores. Molecular and Cellular Biology $\mathbf{3 0}$ 295-306. (doi:10.1128/MCB.00662-09)

Tunster SJ, Van de Pette M \& John RM 2011 Fetal overgrowth in the Cdkn1c mouse model of Beckwith-Wiedemann syndrome. Disease Models \& Mechanisms 4 814-821. (doi:10.1242/dmm.007328)

Tunster SJ, Van de Pette M \& John RM 2012 Impact of genetic background on placental glycogen storage in mice. Placenta 33 124-127. (doi:10.1016/j.placenta.2011.11.011)

Umlauf D, Goto Y, Cao R, Cerqueira F, Wagschal A, Zhang Y \& Feil R 2004 Imprinting along the Kcnq1 domain on mouse chromosome 7 involves repressive histone methylation and recruitment of Polycomb group complexes. Nature Genetics 36 1296-1300. (doi:10.1038/ng1467)

Varrault A, Gueydan C, Delalbre A, Bellmann A, Houssami S, Aknin C, Severac D, Chotard L, Kahli M, Le Digarcher A et al. 2006 Zac1 regulates an imprinted gene network critically involved in the control of embryonic growth. Developmental Cell 11 711-722. (doi:10.1016/j. devcel.2006.09.003)

Verhaagh S, Schweifer N, Barlow DP \& Zwart R 1999 Cloning of the mouse and human solute carrier 22a3 (SIc22a3/SLC22A3) identifies a conserved cluster of three organic cation transporters on mouse chromosome 17 and human 6q26-q27. Genomics 55 209-218. (doi:10.1006/geno.1998. 5639)

Verhaagh S, Barlow DP \& Zwart R 2001 The extraneuronal monoamine transporter Slc22a3/Orct3 co-localizes with the Maoa metabolizing enzyme in mouse placenta. Mechanisms of Development 100 127-130. (doi:10.1016/S0925-4773(00)00510-4)

Wang ZQ, Fung MR, Barlow DP \& Wagner EF 1994 Regulation of embryonic growth and lysosomal targeting by the imprinted Igf2/Mpr gene. Nature 372 464-467. (doi:10.1038/372464a0)

Wang Y, Joh K, Masuko S, Yatsuki H, Soejima H, Nabetani A, Beechey CV, Okinami S \& Mukai T 2004 The mouse Murr1 gene is imprinted in the adult brain, presumably due to transcriptional interference by the antisense-oriented U2af1-rs1 gene. Molecular and Cellular Biology 24 270-279. (doi:10.1128/MCB.24.1.270-279.2004)

Wang X, Sun Q, McGrath SD, Mardis ER, Soloway PD \& Clark AG 2008 Transcriptome-wide identification of novel imprinted genes in neonatal mouse brain. PLoS ONE 3 e3839. (doi:10.1371/journal.pone.0003839)

Wang X, Soloway PD \& Clark AG 2011 A survey for novel imprinted genes in the mouse placenta by mRNA-seq. Genetics 189 109-122. (doi:10.1534/genetics.111.130088)

Watson ED \& Cross JC 2005 Development of structures and transport functions in the mouse placenta. Physiology 20 180-193. (doi:10.1152/ physiol.00001.2005)

West JD, Frels WI, Chapman VM \& Papaioannou VE 1977 Preferential expression of the maternally derived $X$ chromosome in the mouse yolk sac. Cell 12 873-882. (doi:10.1016/0092-8674(77)90151-9)

Wevrick R \& Francke U 1997 An imprinted mouse transcript homologous to the human imprinted in Prader-Willi syndrome (IPW) gene. Human Molecular Genetics 6 325-332. (doi:10.1093/hmg/6.2.325)

Winking H \& Silver LM 1984 Characterization of a recombinant mouse T haplotype that expresses a dominant lethal maternal effect. Genetics 108 1013-1020.

Wood AJ, Bourc'his D, Bestor TH \& Oakey RJ 2007a Allele-specific demethylation at an imprinted mammalian promoter. Nucleic Acids Research 35 7031-7039. (doi:10.1093/nar/gkm742)

Wood AJ, Roberts RG, Monk D, Moore GE, Schulz R \& Oakey RJ 2007b A screen for retrotransposed imprinted genes reveals an association between $X$ chromosome homology and maternal germ-line methylation. PLoS Genetics 3 e20. (doi:10.1371/journal.pgen.0030020)

Wroe SF, Kelsey G, Skinner JA, Bodle D, Ball ST, Beechey CV, Peters J \& Williamson CM 2000 An imprinted transcript, antisense to Nesp, adds complexity to the cluster of imprinted genes at the mouse Gnas locus. PNAS 97 3342-3346. (doi:10.1073/pnas.97.7.3342) 
Wutz A, Smrzka OW, Schweifer N, Schellander K, Wagner EF \& Barlow DP 1997 Imprinted expression of the Igf $2 r$ gene depends on an intronic CpG island. Nature 389 745-749. (doi:10.1038/39631)

Wutz A, TheussI HC, Dausman J, Jaenisch R, Barlow DP \& Wagner EF 2001 Non-imprinted Igf $2 \mathrm{r}$ expression decreases growth and rescues the Tme mutation in mice. Development 128 1881-1887.

Wylie AA, Pulford DJ, McVie-Wylie AJ, Waterland RA, Evans HK, Chen YT, Nolan CM, Orton TC \& Jirtle RL 2003 Tissue-specific inactivation of murine M6P/IGF2R. American Journal of Pathology 162 321-328. (doi:10.1016/S0002-9440(10)63823-0)

Wynne F, Ball M, McLellan AS, Dockery P, Zimmermann W \& Moore T 2006 Mouse pregnancy-specific glycoproteins: tissue-specific expression and evidence of association with maternal vasculature. Reproduction 131 721-732. (doi:10.1530/rep.1.00869)

Yamasaki K, Joh K, Ohta T, Masuzaki H, Ishimaru T, Mukai T, Niikawa N, Ogawa M, Wagstaff J \& Kishino T 2003 Neurons but not glial cells show reciprocal imprinting of sense and antisense transcripts of Ube3a. Human Molecular Genetics 12 837-847. (doi:10.1093/hmg/ddg106)

Yan C, Hongjuan H, Yanjiang X, Zhengbin H, Kai L, Fengwei Z, Jing H \& Qiong W 2011 Expression patterns of imprinted gene Inpp5f-v3 during mouse brain development. Journal of Molecular Histology 42 167-173. (doi:10.1007/s10735-011-9321-y)

Yevtodiyenko A \& Schmidt JV 2006 Dlk1 expression marks developing endothelium and sites of branching morphogenesis in the mouse embryo and placenta. Developmental Dynamics 235 1115-1123. (doi:10.1002/ dvdy.20705)

Yevtodiyenko A, Carr MS, Patel N \& Schmidt JV 2002 Analysis of candidate imprinted genes linked to Dlk1-Gtl2 using a congenic mouse line. Mammalian Genome 13 633-638. (doi:10.1007/s00335-002-2208-1)
Yu LS, Yu S, Yu D, Lee E, Eckhaus M, Lee R, Corria Z, Accili D, Westphal H \& Weinstein LS 1998 Variable and tissue-specific hormone resistance in heterotrimeric Gs protein alpha-subunit (Gsalpha) knockout mice is due to tissue-specific imprinting of the gsalpha gene. PNAS 95 8715-8720. (doi:10.1073/pnas.95.15.8715)

Zhou QY, Quaife CJ \& Palmiter RD 1995 Targeted disruption of the tyrosine hydroxylase gene reveals that catecholamines are required for mouse fetal development. Nature 374 640-643. (doi:10.1038/ 374640a0)

Zhou Y, Cheunsuchon P, Nakayama Y, Lawlor MW, Zhong Y, Rice KA, Zhang L, Zhang X, Gordon FE, Lidov HG et al. 2010 Activation of paternally expressed genes and perinatal death caused by deletion of the Gtl2 gene. Development 137 2643-2652. (doi:10.1242/dev. 045724)

Zwart R, Sleutels F, Wutz A, Schinkel AH \& Barlow DP 2001 a Bidirectional action of the Igf $2 \mathrm{r}$ imprint control element on upstream and downstream imprinted genes. Genes and Development 15 2361-2366. (doi:10.1101/ gad.206201)

Zwart R, Verhaagh S, Buitelaar M, Popp-Snijders C \& Barlow DP 2001b Impaired activity of the extraneuronal monoamine transporter system known as uptake-2 in Orct3/Slc22a3-deficient mice. Molecular and Cellular Biology 21 4188-4196. (doi:10.1128/MCB.21.13.4188-4196. 2001)

Received 20 December 2012

First decision 25 January 2013

Accepted 25 February 2013 